OAK RIDGE NATIONAL LABORATORY

masrow madalstra

\title{
Intermediate Evaluation of USAID/Cairo Energy Policy Planning Project
}

\author{
T. J. Wilbanks \\ W. F. Barron \\ A. M. Karnel \\ H. T. Santiago \\ S. B. Wright
}

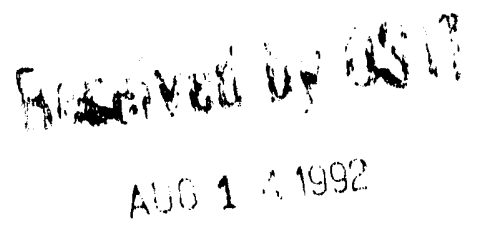

\section{MANAGED BY}

MARTIN MARIETTA ENERGY SYSTEMS, INC.

FOR THE UNITED STATES

DISTRIBUTIUN OF THIS LULUMERI IS UNLIMIEN OEPARTMENT OF ENEREY 
This report has been reproduced directly from the best available copy.

Available to DOE and DOE contractors from the Office of Scientific and Technical Information, P.O. Box 62, Oak Ridge, TN 37831; prices available from (615) 576.8401, FTS 626.8401.

Available to the public froin the National Technical Information Service. U.S. Department of Cornmerce, 5285 Port Foyal Fid., Springtield, VA 22161.

NTIS price codes-Printed Copy: AO3 Microfiche AO1

This report was prepared as an account of work sponsored by an agency of the United States Government. Neither the United States Government nor any agency thereof, nor any of their employees, makes any warranty, express or implied, or assumes any legal liability or responsibility for the accuracy, cornpleteness, or usefuiness of any information, apparatus, product, or process disclosed, or represents that its use would not infringe privately owned rights. Reference herein to any spacific commercial profuct, process, or service by trade name, trademark, manufecturer, or otherwise, does not necessarily constitute or imply its endorsement, recomrnendation, or favoring by the United States Giovernment or any agency thereot. The views and opinions of authors expressed herein do not necessariiy state or reflect those of the United States Government or any agency thereot. 


\title{
ENERGY DIVISION
}

\section{INTERMEDIATE EVALUATION OF USAID/CAIRO ENERGY POLICY PLANNING PROJECT}

\author{
T. J. Wilbanks \\ W. F. Barron* \\ A. M. Kamel ${ }^{+}$ \\ H. T. Santiago $\neq$ \\ S. B. Wright
}

*University of Hong Kong; formerly Oak Ridge Associated Universities.

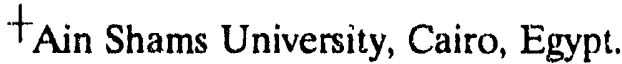

†U.S. Department of Energy, Washingtion, DC.

Conducted by the Oak Ridge National Laboratory in collaboration with the U.S. Department of Energy

through the Energy Policy Development and Conservation Project of the Office of Energy,

Science and Technology Bureau,

U.S. Agency for International Development

Prepared by the

DAK RIDGE NATIONAL LABORATORY

Oak Ridge, Tennessee 37831-6184

managed by

MARTIN MARIETTA ENERGY SYSTEMS, INC.

for the

U.S. DEPARTMENT OF ENERGY under contract DE-AC05-84OR21400 
CONTENTS

Page

PREFACE $\ldots \ldots \ldots \ldots \ldots \ldots \ldots \ldots \ldots \ldots \ldots \ldots \ldots \ldots \ldots \ldots \ldots \ldots$

EXECUTIVE SUMMARY $\ldots \ldots \ldots \ldots \ldots \ldots \ldots \ldots \ldots \ldots \ldots \ldots \ldots$ vii

SUMMARY OF FINDINGS $\ldots \ldots \ldots \ldots \ldots \ldots \ldots \ldots \ldots \ldots \ldots \ldots \ldots \ldots$

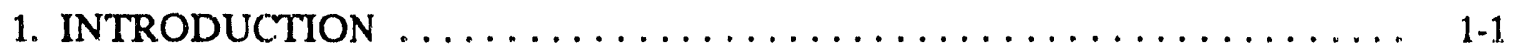

1.1 PURPOSE OF EVALUATION $\ldots \ldots \ldots \ldots \ldots \ldots \ldots \ldots \ldots \ldots \ldots \ldots \ldots \ldots \ldots$

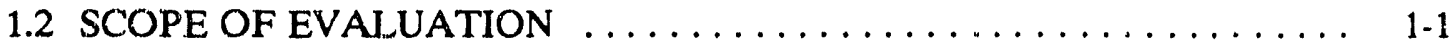

1.3 TEAM COMPOSITION, SCHEDULE AND APPROACH $\ldots \ldots \ldots \ldots \ldots \quad 1-2$

2. OVERVIEW OF THE ENERGY POLICY PLANNING PROJECT IN

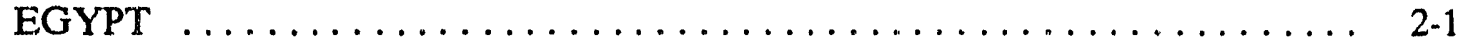

2.1 ORIGINS AND ORIGINAL DESIGN $\ldots \ldots \ldots \ldots \ldots \ldots \ldots \ldots \ldots \ldots$

2.2 ECONOMIC, POLITICAL, AND SOCIAL CONTEXT $\ldots \ldots \ldots \ldots \ldots .2-2$

2.3 IMPLEMENTATION HISTORY $\ldots \ldots \ldots \ldots \ldots \ldots \ldots \ldots \ldots \ldots \ldots$

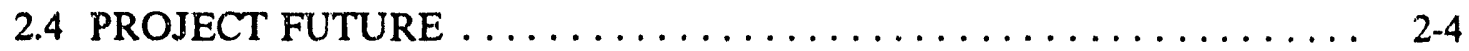

3. PROJECT DESIGN AND IMPLEMENTATION $\ldots \ldots \ldots \ldots \ldots \ldots \ldots \ldots$

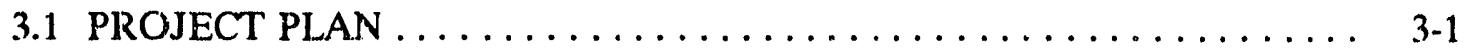

3.2 TECHNICAL ASSISTANCE $\ldots \ldots \ldots \ldots \ldots \ldots \ldots \ldots \ldots \ldots \ldots \ldots \ldots$

3.3 USAID/GOE COLLABORATION $\ldots \ldots \ldots \ldots \ldots \ldots \ldots \ldots \ldots \ldots \ldots$

4. INSTITUTION-BUILDING AND PROFESSIONAL DEVELOPMENT IN THE ORGANIZATION FOR ENERGY PLANNING $\ldots \ldots \ldots \ldots \ldots \ldots .4-1$

4.1 STAFF DEVELOPMENT AND CAPABILITIES $\ldots \ldots \ldots \ldots \ldots \ldots \ldots$

4.2 ORGANIZATIONAL CAPABILITIES $\ldots \ldots \ldots \ldots \ldots \ldots \ldots \ldots \ldots . \ldots \ldots$ 


\section{CONTENTS}

Page

4.3 RELATIONSHIPS WITH OTHER PARTIES $\ldots \ldots \ldots \ldots \ldots \ldots \ldots \ldots$. 4.2

4.4 VIABILITY AND SUSTAINABILITY OF OEP $\ldots \ldots \ldots \ldots \ldots \ldots \ldots$

5. PROGRAMMATIC ACTIVITIES OF THE ORGANIZATION FOR

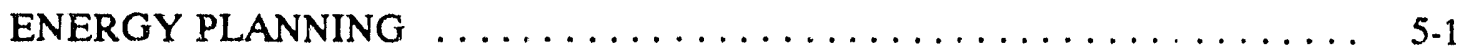

5.1 INDUSTRIAL ENERGY EFFICIENCY IMPROVEMENT PROGRAM . . 5-1

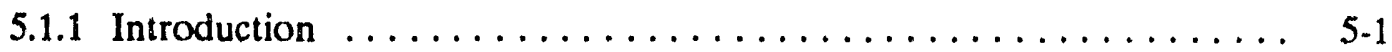

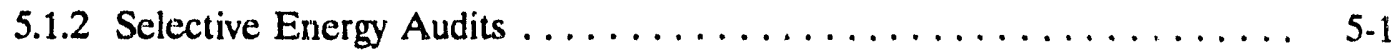

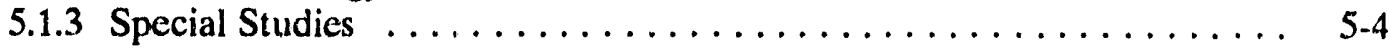

5.1 .4 Energy Management Training $\ldots \ldots \ldots \ldots \ldots \ldots \ldots \ldots \ldots$

5.2 ENERGY PLANNING AND ANALYSIS PROGRAM ......... $5-6$

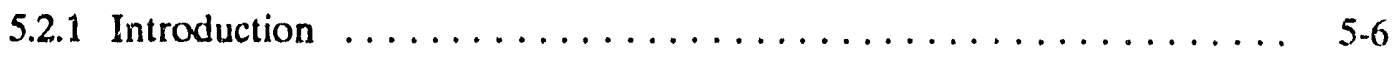

5.2 .2 Tools for Energy Modeling and Analysis $\ldots \ldots \ldots \ldots \ldots \ldots \ldots \ldots$ 5-7

5.2 .3 Data Base ........................... 5.9

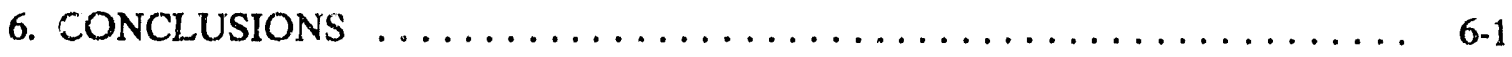

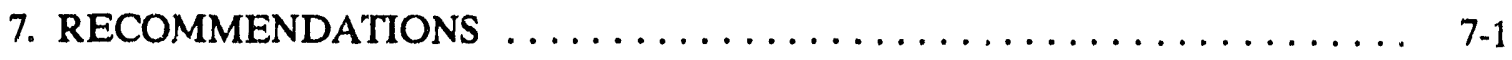

APPENDIX A SCOPE OF WORK $\ldots \ldots \ldots \ldots \ldots \ldots \ldots \ldots \ldots \ldots \ldots \ldots \ldots$

APPENDIX B. LOGICAL FRAMEWORK FOR PROJECT $\ldots \ldots \ldots \ldots \ldots$ B-1

APPENDIX $C$. LIST OF DOCUMENTS CONSULTE $\ldots \ldots \ldots \ldots \ldots \ldots \ldots$ C.1

APPENDIX D. INDIVIDUALS AND AGENCIES CONTACTED ......... D-1

APPENDIX E. I.ESSONS LEARNED FOR OTHER PROJECTS $\ldots \ldots \ldots \ldots$ E-1

APPENDIX F. CRITIQUE OF LOG FRAME $\ldots \ldots \ldots \ldots \ldots \ldots \ldots \ldots$ F-1

APPENDIX G. INDUSTRIAL ENERGY AUDIT PROGRAM $\ldots \ldots \ldots \ldots$ G-1

A.PPENDIX $H$. OEP ACTIVITY IMPLEMENTATION $\ldots \ldots \ldots \ldots \ldots \ldots, H-1$

APPENDIX I. LIST OF ACRONYMS $\ldots \ldots \ldots \ldots \ldots \ldots \ldots \ldots \ldots \ldots \ldots \ldots \ldots$ 


\section{PREFACE}

Three years ago, a team from the Oak Ridge National Laboratory and the Oak Ridge Associated Universities, supplemented by an expert from the U.S. Department of Energy and a senior Egyptian energy professional, carried out what was termed an "intermediate evaluation" of a major energy policy project in Egypt. Supported by USAID/Cairo, the project had concentrated on developing and strengthening an Organization for Energy Planning (OEP) within the Government of India, and it was actually scheduled to end less than a year after this evaluation.

The evaluation was submitted to USAID/Cairo and circulated elsewhere in the U.S. Agency for International Development and the Government of Egypt as an internal report. Over the next several years, the USAID energy planning project ended and the functions performed by OEP were merged with planning capabilities in the electric power sector.

Now that the major issues addressed by the evaluation report have been resolved, we are making it available to a broader audience as a contribution to the general literature on development project evaluation and institution-building. 


\section{EXECUTIVE SUMMARY}

In 1982, USAID approved an "Energy Policy Planning, Renewable Energy Field Testing, and Utility Management Project" (263-0123.1) for Egypt. Under the terms of this project, an "Energy Policy Planning" subproject (263-0123.1), referred to in the evaluation as "the project," was initiated. Section VI of the subproject Project Paper called for initial, intermediate, and end-of-project external evaluations to be conducted.

This report is the intermediate evaluation called for by the Project Paper. As outlined in the Scope of Work, its purposes are: (1) to determine the extent to which the project goals and objectives described in project agreements are being pursued and (2) to recommend ways to assure that the project in its remaining months will respond to the needs of Egypt, in consonance with AID policy guidelines. The evaluation was carried out during the period 26 March-13 April, 1989.

The USAID/Cairo energy policy planning project began in the fall of 1983 , calling for assistance to the Government of Egypt (GOE) in institution-building, professional development, and special studies related to energy planning. The objective was to institutionalize a capability within GOE to analyze energy policy options being considered by energy policymakers. The project was set for a five-year lifetime, ending December 1988 (later amended to June 1990), and budgeted at $\$ 8.5$ million in USAID funds and $\$ 4.2$ million in GOE in-kind and cash contributions.

As a part of the project agreement, GOE established an Organization for Energy Planning (OEP), reporting to the Minister of Petroleum, originally to provide technical support for Egypt's Supreme Councis on Energy (SCE). During the projert, OEP was supported first by the Argonne National Laboratory (1983-86) arid then, after an interim period of about one year, by Meta Systems under a host-country contract. In its early years, OEP emphasized an industrial energy conservation program which remains a major part of its portfolio. In the past year or less, under the active leadership of OEP's third chairman, Eng. Ibrahim Hassaan, assisted by Meta Systems, OEP has upgraded its capabilities for energy policy studies and is seeking an enhanced role in national energy policymaking. 
On the basis of its information-gathering -- including extensive briefings, interviews, document reviews, field site visits, and discussion -- the evaluation team concludes that:

(1) The primary objective of the project, institution-building, has been substantially achieved from the standpoint of capability development in energy planning and analysis.

(2) OEP has become a significant resource for energy planning and policymaking in Egypt, and this potential can be realized through concerted action by USAID and GOE in the remaining period of the project. More specifically:

(a) This final-year effort will call for a more effective working relationship between USAID/Cairo and OEP than has existed at several stages in the project to date.

(b) The institutional location of OEP as responsible to the Minister of Petroleum is not a binding constraint on the Organization's ability to contribute to energy planning in Egypt.

(c) As impressive as they are, OEP's capabilities for policy studies are not well-known to AID and GOE.

(d) If the objectives of the project are to be achieved, OEP needs to add to its record of contributing to industrial energy conservation awareness a record of making a difference for energy decisions in Egypt: a record of contributing to energy planning and policymaking in the country.

(e) OEP needs to enhance the ability of its staff to appreciate energy issues from the policymaker's point of view and to communicate effectively with a policymaker audience.

(3) During the final year of the project, the focus of OEP's activities should be refined, considering national needs and OEP's place in the national energy policymaking system.

(4) In order to sustain the institution-building accomplished by the project, technical assistance should be continued after the end of the project on a more focused basis and at a more modest scale. 
(5) The energy conservation programs of OEP have had a positive impact on energy utilization in industries, but OEP's future roles in this sector require clarification.

(6) Both the Argo Ine and Meta Systems contracts have been fruitful.

The team recommends that the following steps be taken before the end of the current project in June 1990:

(1) USAID/Cairo should:

(a) Assure that appropriate USAID staff are fully familiar with OEP purposes and capabilities.

(b) Support and participate in dialogues with GOE to expand OEP's channels for communicating perspectives.

(c) Work closely with OEP regarding priorities for the final year of the project.

(d) Assure effective coordination with OEP in connection with new USAID/Cairo energy project initiatives.

(e) Identify and explore alternatives for a new cnergy planning assistance mechanism.

(2) OEP should:

(a) Prepare for possible changes in its financial support base with the end of the current project.

(b) Emphasize openness and outreach in establishing the important roles that its capabilities are ready to support.

(c) Continue its shift of emphasis toward policy studies and recommendations, focused on high-priority issues for energy policymaking in Egypt. More specifically, OEP should:

- Aggressively relate its policy analysis capabilities to its strong position relative to the role of conservation in Egyptian energy policy.

- Seek opportunities to increase its attention to petroleum and natural gas policy issues. 
- Continue its attention to energy pricing issues, related closely to dialogues with policymakers about priorities for analysis.

(d) Build OEP staff skills in communicating with energy policymakers as well as fellow technical experts.

(e) Expose OEP staff to a broad range of international experience with policy analysis and modeling. 


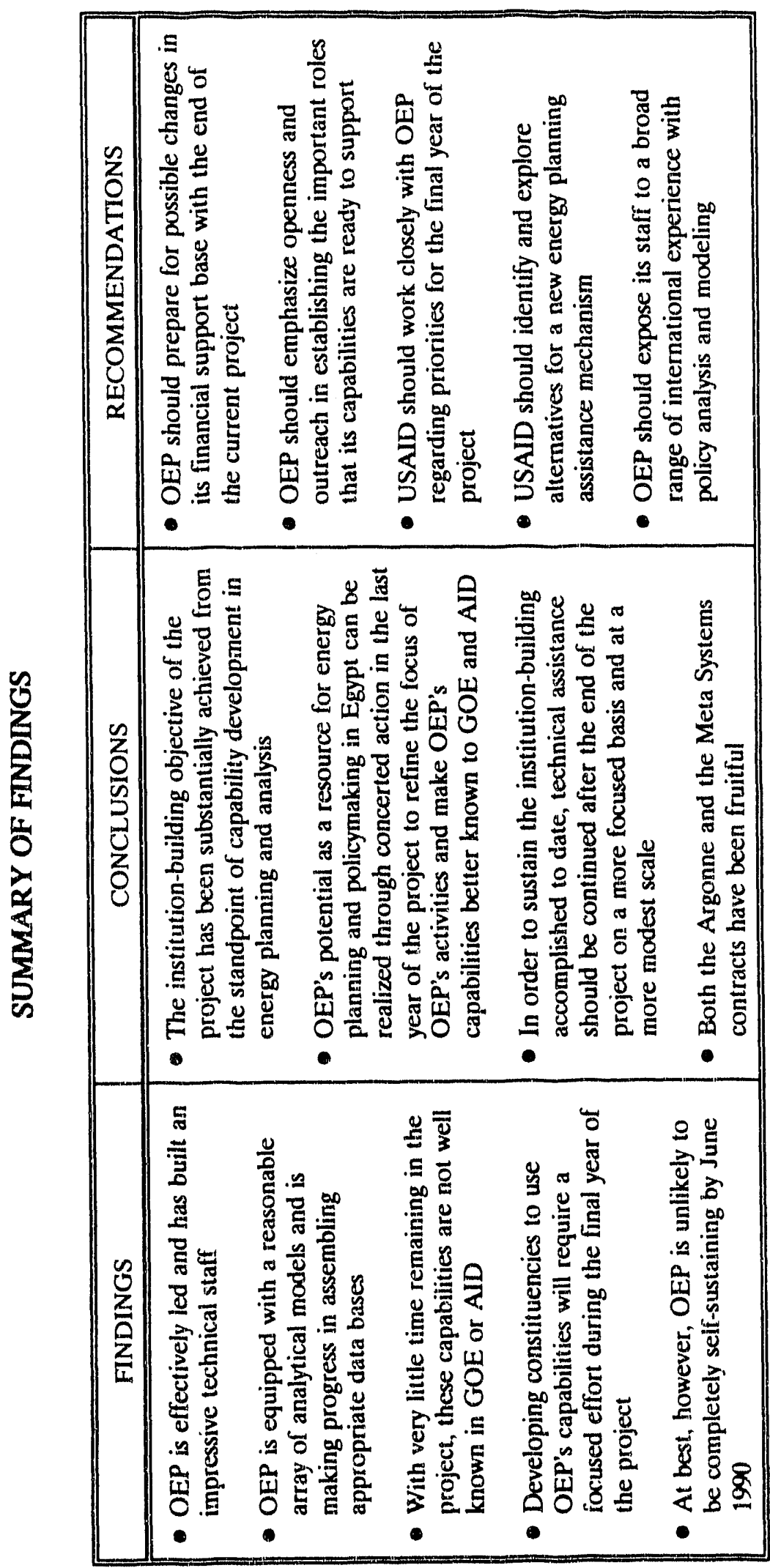




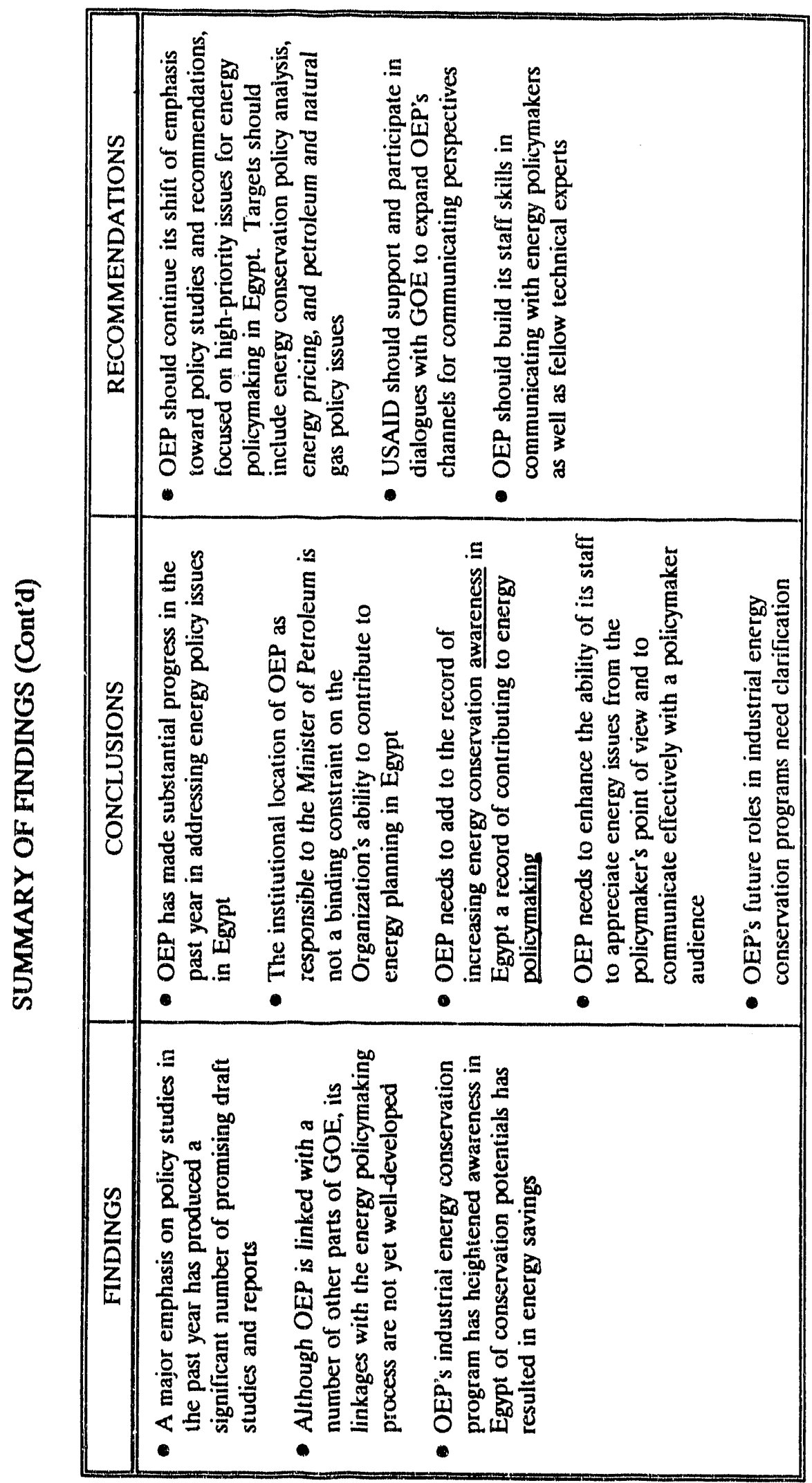




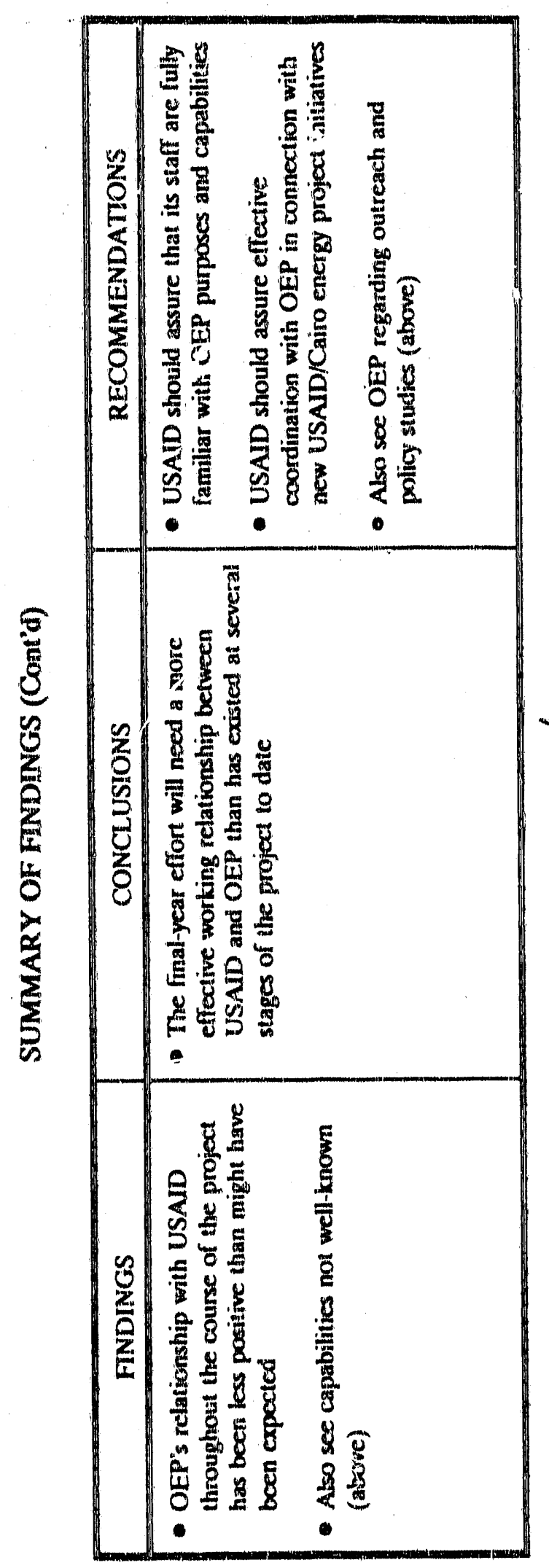




\section{INTERMEDIATE EVALUATTON OF USAID/CAIRO ENERGY POLICY PLANNING PROJECT}

\section{INTRODUCTION}

In 1982, USAID approved an "Energy Policy Planning, Renewable Energy Field Testing, and Utility Managenent Project" (263-0123) for Egypt. Under the terms of this project, an "Energy Policy Planning" subproject (263-0123.1), heieafter referred to as "the projest," was initiated. Section VI of the subproject Project Paper called for initial, intermediate, and end-of-project external evaluations to be conduc ad.

This report is the intermediate evaluation called for by the Project Paper; it is focused on the activities of the Organization for Energy Planning (OEP) of the Government of Egypt (GOE), established as a direct result of the project.

\subsection{PURPOSE OF EVALUATION}

The intermediate evaluation is intended: (1) to determine the extent to which the project goals and objectives described in the Project Paper (PP), Project Agreement, and subsequent Project Implementation Letters are being pursued and are likely to be met within the Life of Project, and (2) to recommend ways to assure that the project in its remaining months will respond to the needs of Egypt, in consonance with AID policy guidelines.

\subsection{SCOPE OF EVALUATTON}

Given these purposes, the evaluation addresses more than the accomplishment of initial project goals alone, even though progress in this respect to date has been significant. More broadly, it considers the challenge of encouraging efficient energy utilization in Egypt as a fundamental aspect of national development, emphasizing possible directions for the Energy Policy Planning Projec! in applying its remaining time and funds to this challenge. 
These issues were considered by the evaluation team in connection with the major elements of the project as it has evolved: institution-building, professional development, industrial energy efficiency improvement, and energy planning nnd policy studies. The full evaluation Scope of Work is attached as Appendix A.

\subsection{TEAM COMPOSITION, SCHEDULE AND APPROACH}

The evaluation was carried out during the period 26 March-13 April 1989, by a team arranged partly through a "buy-in" to the Energy Policy Development and Conservation Project of AID's Office of Energy, Science and Technology Bureau (S\&T/EY). Under this buy-in, the Oak Ridge National Laboratory (ORNL) provided team leadership, a team economist, and administrative support, which was supplemented by an internationai energy planner from the U.S. Department of Energy (DOE) and an Egyptian energy professional. The team consisted of:

- T. Wilbanks, ORNL

- W. Barron, Oak Ridge Associated Universities

- H. Santiago, DOE

- Dr. Ali Mohamed Kamel, Emeritus Professor of Mechanical Engineering, Ain Shams University, Cairo

Administrative support and technical perspectives were provided by $\mathrm{S}$. Wright and

D. Waddle from ORNL, with advice and further perspectives from $D$. Jhirad, manager of S\&T/EY's energy planning and policy development program.

The team combined reviews of documents and written materials with briefings by USAID/Cairo and OEP; interviews of OEP staff, AID staff, and other knowledgeable parties; field visits to several facilities which have been impacted by OEP activities; and intensive interaction among the team members to develop consensus views. Documents consulted are listed in Annex $C$, and individuals and agencies contacted are listed in Annex D.

In order to assure the broadest possible particingtion in the evaluation process, the process began with workshops at USAID/Cairo and OEP to discuss the scope of work. Briefings were held at USAID and OEP a week before the end of the in-country portion of the cvaluation to discuss major findings and invite comments about issues of particular 
interest. A first draft evaluation document was submitted for review four days before the end of the in-country period, and discussion sessions with USAID and OEP were held two days later. Subsequent mieetings took place with both USAID and OEP, and a revised draft report was submitted for comment. Comments on that draft by USAID and OEP have been incorporated in this final report. 


\section{OVERVIEW OF THE ENERGY POLICY PLANNING PROJECT IN EGYPT}

\subsection{ORIGINS AND ORIGINAL DESIGN}

The USAID/Cairo-Government of Egypt energy policy planning project grew out of several developments in the late 1970's and early 1980's. At a global level, looking at the experience of the 1970's, development assistance officials had generally concluded that most developing countries needed institution-building assistance to improve their ability to analyze energy issues and develop energy strategies; and a number of programs for energy planning assistance were taking shape. Within Egypt, in 1978-79, the U.S. Department of Energy (DOE)'s Country Energy Assessment Program had assembled and analyzed a variety of energy data, demonstrating to Egyptian officials and professionals the need for energy planning and modeling capa'ilities. Meanwhile, USAID/Cairo was encouraging GOE attention to such issues as energy pricing and renewable energy potentials, and there was broad agreement that an enhanced ability within the Government of Egypt (GOE) to conduct energy analysis was a necessary part of a more general energy program strategy. Moreover, during this same time, GOE had created a Supreme Courcil on Energy which was designed to help set energy policy directions for the nation, and it appearad to need technical assistance from within GOE.

With this background, a relatively large project was proposed by USAID/Cairo in 1981, titled "Energy Policy Planning, Renewable Energy Field Testing, and Utility Management Grant" (Project 26,-0123). One part of the project was an "Energy Policy Planning Subproject" (263-0123.1). As described in the 1982 Project Paper (PP), the policy planning component was intended to "institutionalize the capacity within the Egyptian government to collect and analyze data necessa y for national energy planning," in order to enable GOE to analyze in a systematic and continuing manner the energy policy options being considered by high-level policymakers. On August 28, 1983, an amended Activity Grant Agreement (PROAG) between GOE and USAID was signed, initiating the larger project of which the energy policy planning activity was a part. The agreement provided for USAID assistance to GOE in institution-building, professional development, and special studies related to energy planning. The total funding level for 
energy policy planning was set at $\$ 8.5$ million in USAID funds and $\$ 4.2$ million in Egyptian in-kind and cash contributions, or a total of $\$ 12.7$ million. The original time period was set at five years, ending December 1988 (later amended to June 1990).

According to the PP and the PROAG, GOE was to establish an Organization for Energy Planning and Analysis (OEPA), which would provide technical support to the Supreme Council on Energy (SCE) and serve as the focus for institution-building and other activities of the project. On April 16, 1983 the Organization for Energy Planning (OEP) was established by Presidential Decree. OEP was defined as an independent legal entity, reporting to the Minister of Petroleum, GOE (who at that time was also Deputy Prime Minister). It was to provide technical support to the Supreme Council on Energy and to be responsible for energy planning for the country.

Under the terms of the project agreement, USAID assistance for project startup would be arranged through a Participating Agency Service Agreement (PASA) with Argonne National Laboratory (ANL), which had been a part of the DOE/GOE Cooperative Energy Assessment in 1978-79. With ANL's help, OEP would take shape and begin operation while a Request for Proposal (RFP) was prepared and issued in order to select a prime contractor for USAID's support. ANL's role began in June 1983, and the RFP was issued in 1985.

\subsection{ECONOMIC, POLITICAL, AND SOCIAL CONTEXT}

The new energy policy planning project arrived during a period of growing financial pressures in Egypt, partly because of lower prices for oil exports but also associated with growing financial requirements to expand electricity generation and with low internal prices for petroleum products and electricity. Energy policymaking in this atmosphere tended to be driven by immediate needs, and most decisions were aimed at responding to urgent pressures at the time, reducing the demand for comprehensive integrated energy planning at a national scale.

During the same time, from the project's origins in 1981-82 to the present, A.I.D. was shifting its energy program emphasis toward policy dialogues on such issues as energy pricing and private sector roles and away from national energy planning. In consultation with GOE, USAID/Cairo was increasingly focusing on power sector issues in its energy 
portfolio. As priorities and personalities at A.I.D. and USAID/Cairo changed, interactions with GOE were understandably affected; and to some degree the interest in the energy policy planning project from the U.S. side shifted toward its potential to contribute to policy dialogue.

\subsection{MPLEMENTATION HISTORY}

The energy policy planning project got started during the Fall of 1983, with OEP under the leadership of Dr. Hussein Abdallah, First Undersecretary, Ministry of Petroleum. During the 1983-85 period, the project was dominated by organizational development (i.e., recruiting staff, acquiring space and equipment, and training) and by an industrial energy audit program, supported by external contractors and consultants. The main purposes of the audit program were: to gather information about energy use, related to OEP's assignment to collect energy data and its belief (supported by USAID) that energy conservation was a policy priority for Egypt; to give OEP a track record of accomplishment during a time when its internal staff capabilities for policy studies were limited and its relation to the policymaking process was unclear; and to serve as a focus for staff recruitment. The most important development in OEP's external environment was the fact that SCE was not operational during this period, leaving OEP as a planning unit entering the energy policymaking process through one of the major players, the Minister of Petroleum.

ANL's role ended in March 1986. Among its contributions was the identification of five priorities for future work by OEP:

1. National energy planning and analysis

2. Energy pricing

3. Industrial energy conservation

4. Transportation energy conservation

5. Electrical energy conservation

By that time, the RFP for a technical assistance contractor had been issued and responses received.

From the spring of 1986 to the spring of 1987 , however, OEP was without a vehicle for USAID assistance, while the selection of the contractor was completed and the 
contract negotiated. Meanwhile, in January 1986, Eng. Abdel Monem Abou El Seoud was appointed as OEP's new Chairman.

The new contractor, Meta Systems, joined the effort in April 1987, with Dr. Franklin Ahimaz as Resident Manager. In July 1987, Eng. Ibrahim Hassaan, formerly Vice Chairman, Operations, of EGPC and Chairman of MISR Petroleum Company, was named the third Chairman of OEP, and the current leadership team was in place. Organizational development since that time has been intensive: continuing OEP's industrial energy conservation program, acquiring tools for energy modeling and analysis, and initiating energy policy studies. The most recent period, from the fall of 1988 to the time of the in-country evaluation, has been especially intensive and productive. OEP's current programs and activities are outlined below in connection with the team's findings.

\section{PROJECT FUTURE}

Under current agreements, the energy policy planning project will end in June 1990, and the Meta Systems contract will end in December 1989. This means that very little time remains to implement findings during the project's lifetime from the intermediate evaluation. 


\section{PROJECT DESIGN AND IMPLEMENTATION}

\subsection{PROJECT PLAN}

The project plan for the energy policy planning project was in many respects a laudable one, with sound goals and strategies and an abundance of perceptive thought about the project's rationale and possible impacts. The team feels, however, that (as is the case for many A.I.D. projects) the project was over-designed if the project plan is taken literally. For example, the task description for institution-building alone is more than twelve pages long, containing detailed directions to the technical assistance team. In fact, a qualified contractor can be expected to perform effectively within more general guidelines. Specific directives at the time of project initiation can reduce the flexibility of project implementation five years later.

The team also feels that, in some cases, the project plan is of only limited value for project evaluation. For instance, the logical framework in the project plan (Appendix B) includes such "objectively verifiable measures" of performance as an evolution of GOE policies to "better reflect economic realities of energy pricing and give more realistic decisionmaking signals." This, in turn, was based on a number of optimistic assumptions about conditions for energy policymaking in Egypt .- conditions over which OEP has little control.

Appendix $\mathrm{F}$ provides a fuller critique of the Log Frame.

\subsection{TECHNICAL ASSISTANCE}

USAID assistance to OEP has been provided through an A.I.D. PASA with the Argonne National Laboratory (1983-86), which had had a previous presence in Egypt, and a USAID-funded host-country contract with Meta Systems (1987-89) awarded through a competitive bidding process.

The arrangement with Argonne (ANL) was difficult for the team to evaluate because so few of the key players on either the U.S. or the GOE side are still in place in Egypt. It appears, however, that ANL was highly effective in developing a good working relationship with OEP's first Chairman and in helping to get OEP rolling as an 
organization. ANL worked in a mode very similar to a host-country contractor, as an adjunct of the new GOE organization rather than as a technical extension of A.I.D. Among its contributions were the establishment of OEP as a working organization; assistance in building the industrial energy conservation program (OEP's first priority at the time); the definition of a clear agenda for energy policy studies by OEP, as well as agendas for computer hardware and software acquisition, library acquisitions, and staff training; and the RFP for a host-country support contractor. Caught in a changing milieu, ANL seems to have focused on OEP's needs for internal institution-building, mainly as defined by OEP's Chairman, rather than on USAID's growing concerns about policy dialogue -- leading to some strains on the A.I.D. side. It is hard to imagine how the project could have been initiated in any other way without a significant delay, and ANL deserves considerable credit for what it accomplished. The problem was that USAID appears not at that time to have been inserted effectively into the loop between OEP and short-term visitors from the U.S. who were already plugged into OEP. This led to a degree of alienation of USAID/Cairo from the project as it evolved during the ANL period.

The gap in USAID technical assistance between the spring of 1986 and the spring of 1987, awaiting the selection and arrival of a host-country contractor, was a major setback for the project. The causes of the interruption seem to have been complex, rooted in differences between Egypt and the United States in normal management styles and contracting practices. But, besides interrupting the continuity of the USAID/GOE relationship and denying OEP technical assistance during a formative period, the gap had a serious adverse impact on the confidence of the two parties in each other, and resulting impressions and suspicions remain a problem today.

The current relationship with Meta Systems to provide technical assistance has proved to be quite effective in meeting many of OEP's needs. Dr. Ahimaz, the Resident Project Manager, is a knowledgeable and experienced professional and has earned the full confidence of the current Chairman. It appears to the evaluation team that Meta Systems has worked mainly in two modes: through behind-the-scenes advice to OEP's Chairman and by arranging external consultants to assist OEP and its staff, sometimes by leading key activities but increasingly by providing on-the-job training. Certainly, the progress of OEP as an energy planning and analysis institution has been most impressive during this period 
and, from what the team can discern, the subcontractors and consultants provided through the Meta Systems contract have been effective in the roles assigned to them. The main issue that emerged during the evaluation was a feeling on the part of some A.I.D. officials that Meta Systems has not been assertive enough in its technical assistance role with OEP and in representing OEP's artivities to USAID/Cairo. It is the team's view that this criticism reflects an imperfect understanding of the realities faced by a host-country contractor.

\subsection{USAID/GOE COLLABORATION}

When this project was initiated, the development of GOE's ability to perform national energy planning was viewed as an important component in a larger energy assistance program. During the course of the project, regular meetings were held between the OEP Chairman and the USAID project officer, and these regular meetings continue to the present.

Despite these regular meetings and additional communications between USAID and Meta Systems, USAID expressed concern to the evaluation team about project priorities, the communication of progress, and the coordination of activities. Many of these difficulties, the team believes, resulied from changes in project officers and from difficulties associated with the transfer of technical assistance responsibilities from ANL to Meta Systems (especially the interruption in assistance).

An additional factor was a tendency within A.I.D. and USAID/Cairo, as energy pricing and capital requirement problems became more acute, to focus on more targeted policy dialogues and assistance programs, rather than assistance to GOE in conducting energy planning and analysis, and therefore to look for different things from the project than GOE thought the bilateral "contract" called for.

Finally, USAID's participation in the project was affected by greatly expanded development assistance programs in Egypt during the 1980's, reducing available staff time to update the knowledge of Mission personnel (beyond the Project Officer alone) about the progress being made in this program. 


\section{INSTITUTION-BUILDING AND PROFESSIONAL DEVELOPMENT IN THE ORGANIZATION FOR ENERGY PLANNING}

\subsection{STAFF DEVELOPMENT AND CAPABILITIES}

With the assistance of the energy policy planning project, OEP has become a substantial institution. At the time of the in-country evaluation, it had a technical staff of 54, up more than 45\% from the number in April 1987. It occupies four floors of an office building in Garden City, convenient to central Cairo. It is equipped with an impressive array of microcomputer hardware and software, including ten IBM PS/2 Model 50 and PS/2 Model 80 micros, and is linked via telecommunications with external data sources in the United States, Europe, and Egypt itself (due to assistance from the USAID/GOE Applied Science and Technology Research Project: 263-0016). It is equipped for "desktop publishing."

The technical staff of OEP consists of engineers, economists, and computer specialists trained mostly or entirely in Egypt, including a number of PhD's, but OEP has encouraged cross-training in both engineering and economics. Nineteen staff members have participated in training courses in the United States; more importantly, most of the staff has worked closely with short-term consultants, especially since mid 1987, receiving on-the-job training as a result. Intensive discussions and questioning indicated that OEP staff involved in both energy conservation and energy policy study activities are talented, competent, and highly motivated. In several cases, given little more than three months of experience with new analytical models, they had developed a remarkable grasp of the tools and were able to interact fully and freely with the team at a high technical level. Although the Meta Systems project manager and a number of consultants, both foreign and Egyptian, had played -- and were continuing to play -- key roles in OEP activities and products, OEP's own staff members were actively involved in most activities and were generally able to field tough questions without assistance. Moreover, many of them had some involvement in several different activities, which has a potential to help integrate the Organization's programs as well as adding resilience as priorities change, and a growing number of activities were under the active hands-on leadership of in-house staff. 


\subsection{ORGANIZATIONAL CAPABILITIES}

OEP continues to evolve as an organization; in fact, its organization chart was in a state of flux during the evaluation period. But the evaluation team found it to be a highly capable, responsive institution. Its Chairman is impressively well-informed, an impassioned believer in the objectives of the project, and certainly fully in charge. In most cases, the next level of management in OEP is also strong; in several cases, it appears to be exceptional.

The team found three kinds of evidence to be especially revealing. First, OEP's preparation for the evaluation was highly professional in both quantity and quality. Second, in several cases (e.g., the ENPEP model and the energy van) the Organization had come up to speed with new tools in a strikingly short period of time. Finally, when the team asked for particular information or for changes in the agenda, OEP -- from top to bottom -- responded in a manner that would make any organization proud. The tearn found OEP to be an organization that works hard, has developed substantial pride in itself, and shows surprising openness and flexibility in its internal dynamics.

\subsection{RELATIONSHIPS WITH OTHER PARTIES}

OEP is in some ways well-linked to other key parties in Egypt's systems for energy policy and energy utilization but in other ways not so well-linked. Its connection with the Minister of Petroleum is, of course, strong; and its links with public-sector industrial corporations are also excellent as a result of OEP's industrial energy audit and energy management training programs. It is well-connected with major parts of the Ministry of Petroleum, largely through the Chairman's own personal contact networks, and -- based on strong interagency participation in presentations to the evaluation team -- appears to have developed effective relationships with such other parties as the Ministries of Planning, Transport, Supplies, Health, and Construction and Housing, CAPMAS, and a number of Egyptian universities.

OEP's relationships with the Ministry of Electricity and Energy, however, have been affected by questions about the division of energy planning responsibilities related to the power sector. The Ministry is represented on OEP's Board of Directors and has sent staff members to OEP's Energy Management Training Course; and OEP, of course, has access 
to published data from the Egyptian Electric Authority (EEA). But OEP is not currently well enough informed about power sector planning in Egypt to be able to incorporate the power sector fully in its national energy planning and analysis.

The team also found that OEP's relationship with USAID/Cairo throughout the course of the project has been less positive than might have been expected. For example, a number of OEP, AID, and contractor staff members reported a history of tensions and disagreements; and a number of letters and memoranda in the project files painted a picture of a rather strained relationship. Noticeable improvement however, has been shown in recent months as the result of regular meetings (see Section $3 \mathrm{c}$ ).

\subsection{VIABILITY AND SUSTAINABILITY OF OEP}

Although the energy policy planning project is not yet complete, it appears to the evaluation team that OEP is already a thoroughly viable organization, from the points of view of staff capabilities, leadership, and facilities. The major questions about viability are relative to OEP's potential to have an impact on energy policy, which depends on its location in the policymaking system and its success during the next year in proving itself to energy planning and policymaking institutions.

Regarding sustainability, if the remaining year or so of the project is used productively, the team believes that OEP is almost certain to have enough in-house technical capabilities to sustain itself without major financial assistance from outside GOE, except for a few relatively specific technical areas (such as energy pricing -- see Section 5).

The central issues about sustainability are likely to be institutional rather than technical, related especially to OEP's need for a long-term institutional and financial base independent of USAID and its current lack of GOE or other "clients" for its work. On the other hand, given the fact that most of the significant institution-building related to policy studies will be only 2-3 years old and given the institutional challenges still to be met, OEP may not be fully prepared to sustain a major role in supporting energy policymaking in Egypt without some further assistance for a limited period of time. The main needs are likely to te bridging assistance while the support base shifts to other parties, as OEP increases its outreach within GOE, and technical assistance related to particular policy issues which cannot be addressed fully by OEP's more general analytical tools. 


\section{PROGRAMMATIC ACTTVTTIES OF THE ORGANIZATION FOR ENERGY PLANNING}

For convenience in this evaluation report, the findings of the team about the programs of OEP will be discussed under two major headings: (a) the industrial energy efficiency improvement program, including audits, inspections, special studies, and management courses, and (b) the energy planning and analysis program, including energy information, energy modeling, and policy studies.

\subsection{INDUSTRIAL ENERGY EFFICIENCY IMPROVEMENT PROGRAM}

\subsubsection{Introduction}

The OEP Industrial Energy Improvement Program was designed to support four major requirements of the subproject:

(a) To promote conservation awareness in industry and build networks into the various industrial sectors to enhance information exchanges.

(b) To develop reliable data on end use energy consumption to allow OEP to perform comprehensive energy analysis.

(c) To identify special energy problens in industry and develop conservation and other initiatives to address and resolve these problems.

(d) Tu provide an opportunity for the OEP technical staff to obtain first-hand knowledge of the energy problems and conservation opportunities in the industrial sector. In the process, this activity also provided a means for recruiting high quality technical staff members to the OEP.

\subsubsection{Selective Energy Audits}

To accomplish these objectives, a program of energy audits ir selected industries was conducted from 1984 through 1988, using funds from the subproject as well as funds from the Government of Sweden.

The decision to conduct energy audits in selected industrial activities was based on the lact that most companies in Egypt lacked the insirumentation needed to provide data required by OEP for its national energy analysis and, in addition, lacked knowledge about 
how to conduct an energy audit and identify Energy Conservation Opportunities (ECO's). The Energy Audit Program filled this gap at least in part; funds to implement the audits were not provided under the project.

(a) Selection of companies and conduct of audit. OEP used an cxplicit set of selection criteria to select companies for audits, including such factors as the following: would the candidate company provide data re ated to ECO's typical of the industrial sector which they represented; was the candidate company a significant consumer of energy; was the candidate company interested in having an energy audit conducted; etc. The evaluation team concluded that the selection criteria provided a reasonably sound and objective mechanism for identifying suitable candidates consistent with the aims of the project, at least under the conditions under which the procedure was originally defined.

Sixteen energy audits have been conducted, eleven using subproject funds and five using funds from a Government of Sweden grant. All of the audits were conducted by U.S. and Swedish firms, with OEP participating actively in the planning and execution of the audits along with company personnel and foreign technical consultants. A review of the audit reports indicates that the audits were conducted in a professional manner. The ECO's identified were grouped into three categories: those which could be performed by in-plant personnel (housekeeping ECO's), those requiring the purchase of equipment from domestic sources, and those requiring equipment from foreign sources.

(b) Results. The evaluation team concluded that, with respect to providing OEP with reliable and accurate end use energy data for the industrial sector and in increasing the knowledge and awareness of OEP staff of the conservation problems and opportunities in this sector, the energy audits were quite useful. The energy audits also successfuily identified a number of special energy problems that OEP is currently investigating and raised the awareness of energy conservation opportunities in the industrial sector. More will be said of the special problems later.

To help evaluate the promotion of energy awareness in industry and contributions to individual plants in reducing energy consumption, the evaluation team visited two industrial plants in Helwan which had had energy audits conducted by OEP: the Helwan Portland Cement Company and the El Nasr Coke and Chemicals Company. At both companies, members of the evaluation team met with senior officials. Both companies 
valued the energy audits conducted and have since initiated actions to perform housekeeping improvements in their plants. Although the energy-saving results of those actions are not yet fully known, on a official in the Cement Company noted that fuel oil consumption (in mazout) has decreased by 4 tons/day as a result of the changes initiated in the boiler house (about $10 \%$ of the total energy consumed in the boiler house). Additionally, both companies have requested funds in their FY $89 / 90$ budget to accomplish the other ECO's identified in the audit reports. Indeed, the El Nasr Coke and Chemicals Co. chairman was encouraged to request these funds by a recent Ministry of Industry directive to its companies, directing them to identify energy conservation measures and request funds to achieve them. These funding requests have not yet been answered, however, and there is some skepticism whether the plants will receive all that they requested.

Based on these two visits, the evaluation team concluded that the energy audits have heightened awar ness of energy conservation in at least two plants and have provided the company chairmen with useful documentation for requesting funds from GOE in order to implement the ECO's.

(c) Followup activities. OEP has obtained one "energy van" to date and outfitted it with an extensive set of instruments to measure, record and analyze various energy data at a plant site. A second van is scheduled to be delivered soon. The purpose of these vans is to monitor energy use at individual plant sites to help plant managers improve their operating performance and reduce energy consumption as well as provide additional, up-to-date data for OEP analysis. Detailed discussions with the OEP staff indicated through knowledge of the use of the instruments. Additionally, a review of some of the data obtained shows that plant managers and operators have, in at least one case, responded to the energy van visits by improving their operational performance. OEP might consider the use of portable sets of instruments independent of the energy van to expand its monitoring operations further.

(d) Relationships with other activities. In reviewing the energy audit program, the evaluation team was made aware of a new initiative by USAID to promote energy conservation in the industrial sector, both public and private. The evaluation team applauds this initiative; but discussions with officials in various institutions, including OEP, 
USAID, the Tabbin Institute for Metallurgical Studies, and the two companies previously mentioned, suggest that effective connections between OEP's industrial energy conservation efforts and the new proposed conservation project should be explored. The U.S. members of the evaluation team believe that the institution building objectives of the energy policy planning project would be well-served by encouraging linkages of this type, and we believe that such a connection would increase the value to Egypt from the investments to date in the planning project.

\subsubsection{Special Studies}

As previously noted, the Industrial Energy Audit activity was also designed to provide further insight into the energy problems and opportunities of the industrial sector. As a result of the audits, a number of initiatives have been identified for OEP for more detailed study. The team reviewed two of these initiatives: cogeneration opportunities and power factor improvements.

(a) Cogeneration. Using information obtained through the energy audit program as well as other information, OEP has conducted initial studies on cogeneration potentials in Egypt. The study considered thirteen industrial firms, tentatively concluding that these companies combined could provide significant quantities of electricity to the grid at a cost which would be roughly half of what electricity from a conventional thermal electricity plant would cost.

OEP has selected three of the companies for more detailed study with the intent of proposing one of them as a demonstration project. Because of the existence of a law which prevents any institution from generating electricity for the national grid besides the Egypt Electricity Authority (EEA), OEP is in the process of preparing documentation (in Arabic) to suggest a change in the law.

The evaluation team's review of these studies, although not detailed, indicates that they are well-conceived and are receiving the full support of the companies involved. The preliminary engineering work conducted so far appears to be competent, and the policy analysis supporting this initiative, while incomplete, is proceeding. With regard to the use of cogeneration to supply power to the electric grid, however, a note of caution is offered. Such a proposal must not lead to lowered reliability for the power system as a whole, and 
further investigation of the reliability issue may be needed before policy proposals are submitted.

(b) Power factor improvement. OEP has also initiated a study to investigate the electrical inefficiency resulting from a low power factor in industrial plants and, where necessary, to promote solutions to this problem. With the aid of faculty members from the Cairo University and industry, OEP has conducted power factor studies at selected plants and has submitted these studies to the appropriate Ministries. This effort is presently being expanded to cover more industries. The team concluded that this effort, if fully implemented, would improve the efficiency of Egypt's industrial base and reduce the demand on the national electrical system.

This and the cogeneration study are representative of the enthusiasm of OEP about pursuing complex policy-oriented energy studies, in conjunction with other Ministries and technical experts, in order to identify and develop policies to enhance efficient energy utilization in Egypt.

\subsubsection{Energy Management Training}

OEP has provided one-week courses in energy management to more than twelve hundred persons throughout the Egyptian industrial sector. At current levels of service, more than five hundred persons per year are participating in these courses. The purposes of the courses are to create awareness of energy use efficiency, to upgrade knowledge and skills, and to help initiate a network of energy managers through which OEP can provide future support and assistance.

The evaluation team was unable to attend an OEP energy management training course or to interview course attendees. The team did, however, review course material and discuss the program with OEP staff and consultants. The team believes that these courses probably serve a useful function in terms of raising awareness, in helping to establish networks among energy managers, and in imparting (to at least part of the participating group) practical information which thesc individuals can directly apply in their work environment.

Unfortunately, the written course needs a considerable amount of further development, a fact recognized by OEP. The existing material is relatively unfocused, and the assumed skill level of the audience varies greatly from one set of lecture handouts or 
notes to another. Much of the material is taken directly from foreign sources, while other parts are a rough inter-splicing of locally prepared lecture notes and previously written background materials from other sources. Finally, the treatment of economics is generally weak (or absent) from most of the written lecture handouts, though the one lecture specifically devoted to economics is well done.

As noted above, OEP recognizes these problems and has started revising the written material for the courses. The evaluation team supports this move, particularly if the result is a shorter, more clearly directed and focused set of materials, aimed at providing the participants with a practical, concise and coherent set of reference documents which they can use in identifying and evaluating energy conservation opportunities.

The main limitation of the course, as presently structured, is that it appears to be almost exclusively in a lecture format, more or less detached from the conditions pertaining to specific job requirements, which raises questions about its training value. It would be useful to solicit suggestions from a range of experts on educational programs, both within Egypt and internationally, about other formats that should be considered.

\subsection{ENERGY PLANNING AND ANALYSIS PROGRAM}

\subsubsection{Introduction}

Tasks 3 through 8 of the SOW outlined in the PP called for the PASA organization (ANL) and later the prime contractor to assist the counterpart organization in the selection, implementation, and use of analytical tools for energy planning. These tools were expected to include various accounting and optimization models, a comprehensive data base to support these models and more general energy planning needs, and the computer hardware/software and other physical support systems needed to effectively utilize these tools. In addition, USAID support was to be used for training counterparts in the design and use of these systems through formal training and on-the-job experience.

The basic direction and certain specific features for the system for planning and analysis were laid out by ANL in Appendix 3.3 to the ANL Final Report of June 1986. At the point of ANL's departure, OEP had a relatively detailed design for its energy planning system and supporting data base. With the arrival of the Meta systems resident advisor, changes were made to the ANL planning system design, but the conceptual 
framework as originally outlined by ANL remained the basis for the OEP analytical system as it was implemented.

\subsubsection{Tools for Energy Modeling and Analysis}

As presently organized, the OEP models are divided into three main groups, represented either by a single integrated model or a series of independent models. These groups are (1) the basic energy supply/demand accounting system and projection framework (represented by the ENPEP integrated system), (2) the energy-economy interaction analysis system (based on the MIT Energy Economy Model), and (3) a set of energy pricing models.

Descriptions of these models as provided by OEP are contained in Appendices 3.1 to 3.3. of OEP's report on programs and activities dated March 1989 (see Appendix C). For the purposes of this evaluation, the major points of interest are: (1) the appropriateness of the models to the energy planning needs of Egypt, including the analytic capabilities and limitations of each, (2) the understanding by OEP staff of the energy planning process and how the underlying structure of these models relate to that process, (3) the ability of OEP staff to maintain and up-date data inputs to these models, particularly after the end of the existing USAID assistance (June 1990), and (4) the uses to which OEP has put or is planning to put the models.

The OEP models as outlined by ANL and as eventually implemented through Meta Systems are, for the most part, highly detailed and relatively complex and sophisticated. In the particular cases of ENPEP and the MIT energy-economy interaction model, the data requirements are substantial and updating will be a major ongoing effort. The evaluation team considers that the overall analytical system centered around these models is at an appropriate level of sophistication, considering Egypt's size and complexity and the capabilities on OEP staff.

ENPEP was designed by ANL with U.S. Department of Energy funding and is in use in a number of developing countries around the world through a World Bank/International Atomic Energy Agency program, Essentially, ENPEP is an accounting system to balance energy supply and demand based on a historical base year, and provides a framework for projecting energy demand requirements for future years. It achieves this balance through an iterative process of top-down (supply-side) and bottom-up (demand- 
side) calculations. Electricity demand projections are treated in considerable detail through a series of modules, including the WASP III dynamic program optimization model which generates the calculated optimal power system expansion plan to meet base intermediate, and peak loads produced from other modules on the basis of assumed growth in certain macro-economic parameters. (As of April 1989, OEP has not operated the WASP III component.) OEP staff appear to have a good understanding of the major components of ENPEP, though much work remains to gain experience in exercising the full model, learning to utilize each of the modules effectively, identifying appropriate questions to address, and understanding ranges of uncertainty in constructing scenarios.

The MIT Energy-Economy Interaction model utilizes a non-linear optimization programming system to track the expected impacts of changes in energy and macroeconomic conditions on the whole economy and on specific sectors. The basic MIT model is quite general and must be tailored to individual countries through appropriate sectoral classifications and parameter value specification. The model was installed in OEP in December of 1988. OEP staff appear to have a reasonably good preliminary understanding of the basic structure of the MIT model, but additional work is needed to adapt it for use in the Egyptian political-economic context.

An energy pricing study is currently (April 1989) under way by a joint Meta Systems/OEP team, including both petroleum product pricing and the pricing of electricity. The Meta Systems/OEP team is looking at the economic costs of petroleum and electricity and is examining the impacts of possible adjustments in financial prices on income distribution, industry competitiveness, and other conditions. The April 1989 electricity price increase offers an opportunity to draw from actual national experience as well as more theoretical analysis.

A related activity is an attempt by OEP and Meta Systems to evaluate price and income elasticities for Egypt. This is a complex undertaking because of Egypt's long history of very low energy prices and a price history where any real price increase is quickly eroded by inflation -- a condition presumably anticipated by consumers in their consumption decisions. OEP and its consultants are attempting to evaluate the available information on consumer responses to changes in prices and incomes in Egypt and are reviewing price and income elasticity estimates for similar countries. 
The OEP staff appear to have a reasonably good understanding of the issues associated with estimating price and income elasticities, though continued outside assistance in the pricing work is probably essential for some time to come. One approach which OEP probably should consider with regard to evaluating the impact of higher real prices is the utilization of its industrial conservation audit data, supplemented as needed by additional data collection, to develop an understanding of the role of specific forms of energy in the overall production functions of various industries. From this, OEP could help to estimate the impact of possible petroleum product and electricity price increases on these industries. Such an effort would complement, but be distinct from, attempts to estimate elasticities econometrically. Also, at least part of the work with ENPEP and the "MIT model" could be directly useful for such analysis. Although more generally applicable policy recommendations should ultimately come out of this type of work, the more immediate goal would be to facilitate discussions within the GOE of the impacts of energy pricing reforms by developing credible data and analyses for selected industries.

During the course of this evaluation, OEP staff demonstrated an impressive understanding of the underlying structure of energy supply and demand balancing and the manner in which the models function and how each structures its projections. This is particularly impressive considering that training in and limited use of these models has been going on for less than a year, as well as the fact that many of the key OEP staff persons have engineering backgrounds, with limited training in economics. The potential risk for OEP in the use of ENPEP, the MIT model, and the pricing models is that staff with limited training in economics may not fully appreciate uncertainties associated with the estimates of income and price elasticity and energy-economy interactions.

\section{2 .3 Data Base}

As of April 1989 the OEP data base is relatively well defined, the computer system has been installed and is operating, many of the historical data have been collected and entered, and efforts are under way to fill in the remaining gaps.

Accurate, up-to-date data are essential to conduct reliable analyses of policy options and to assess the energy and economic implications of these options. The specific data required will, of course, depend on the particular analytic procedure to be used. For example, ENPEP requires accurate end-use energy consumption data such as: steam 
raising per unit of output, process heat per unit of output, motive power, lighting, transportation (or transmission) and conversion efficiencies, etc.

A review of the data base available to OEP to exercise the ENPEP model indicates that, with the major exception of certain information on the electricity sector and selected data in other areas, much of the data associated with energy supply appears to be reasonably well-developed. Although considerable data on industrial end-use have been developed, however, gaps on the demand side remain. OEP's interest in reducing such gaps is one motivation for its continued work in industrial energy audits and monitoring. Other important gaps exist in the transportation and household sectors. Data for the pricing and MIT models appear to be reasonably complete and draw heavily on information from such organizations as CAPMAS and the Ministry of Planning. However, it is important to note that OEP's efforts to evaluate data consistency and validity are still at a relatively early stage.

In view of the need for OEP to improve its data base size and quality, OEP's caution in producing and releasing critically important policy studies is understandable. With this said, the evaluation team also believes that OEP must begin to become much more open with its data and studies, even at the risk that some errors or deficiencies will become evident to those outside the organization.

Besides its statistical data bases, OEP has also created a broader Energy Information Center (EIC) to meet the needs of its staff and others for a wide range of information, including bibliographic data. According to records maintained at the Center, more than a dozen external organizations have used EIC services to date. The evaluation team was impressed with the design of EIC, the capabilities of its staff, and the equipment and other tools being used. In almost every respect, the Center is prepared to operate at an international standard, where the data sources available to it are adequate. Its computer equipment is superior to many comparable organizations in the United States, and the staff responded in a highly professional manner to each and every challenge to demonstrate the Center's capabilities. Moreover, the staff showed enviable pride in their work, and morale was high. The main challenge is to continue efforts to build the bibliographic data base related to Egyptian reference materials, the OEP Library, and other data sources in order to take full advantage of the Center's capabilities. For 
instance, in a number of cases the bibliographic data called up in answer to questions by the team missed important standard references on the subjects specified -- a problem not of EIC staff limitations but of the data bases available to them. 


\section{CONCLUSIONS}

From these findings, the evaluation team concludes that:

a. The primary objective of the project, "to assist the GOE to strengthen its institutional capability to establish and maintain an energy information base and to conduct ... analyses of energy ... needs in support of ... energy planning" (see Log Frame, Annex B), has bcen substantially achieved. Institution-building for OEP has been a notable success, from the standpoint of capabilities for planning and analysis. More specifically, the team finds that:

(1) OEP has strong, forceful, effective leadership which is actively pursuing the roles for the Organization defined in the Project Plan.

(2) OEP has developed staff capabilities that may well be unmatched in a single energy planning institution in any other AID-assisted country in the world, according to the experience of evaluation team members.

(3) The industrial energy audit program and other energy conservation programs have been effective stepping-stones for institution-building. These programs have helped to establish OEP as a credible, legitimate institution, to assemble a talented staff, and to identify policy directions of value to Egypt.

(4) OEP has established strong linkages with Egypt's industrial sector and appears to be developing effective linkages with other sectors as well. Steps toward enhanced relationships with the electric power sector are especially welcome.

b. OEP has become a significant resource for energy planning and policymaking in Egypt, and this potential can be realized through concerted action by USAID and GOE in the remaining period of the project. More specifically, the team finds that:

(1) This final-year effort will call for a more effective working relationship between USAID/Cairo and OEP than has existed at several stages in the project to date. Although there are encouraging signs of recent improvements, through most of its history the energy policy planning project has not had a strong, positive relationship between the two main parties in 
this bilateral collaboration. The reasons are complex, combining changes in external conditions, the personalities of key individuals, and staff overcommitment at USAID. But a general result has been that attitudes have developed which are not conducive to effective collaboration in institution-building for energy planning.

(2) The institutional location of OEP as responsible to the Minister of Petroleum is not a binding constraint on the Organization's ability to contribute to energy planning in Egypt. The energy policy planning project was designed with the existence of a GOE Supreme Council on Energy in mind, for which OEP was to serve as a planning and analytical organization. Because the Supreme Council has not met as such, in one sense OEP's main "audience" has been erased. On the other hand, the Minister of Petroleum is a supportive channel for OEP recommendations, and OEP's information, analysis, and perspectives can find their way into use in a variety of ways when they are sound and actively communicated. The team was especially interested to learn that, although SCE does not meet as such, it has established four groups to provide advice to national leaders on energy policy matters, and OEP is linked to three of the groups through its Board of Directors. This offers some promise that a rather wide-ranging role for OEP could develop.

(3) As impressive as they are, OEP's capabilities for policy studies are not wellknown to AID and GOE. At least partly because OEP has recently been engaged in a major internal effort to upgrade its policy analysis capabilities, waiting to assure the quality of its work before issuing it, the Organization has not yet "made a splash" as a policy-oriented institution (in contrast to its contributions to industrial energy conservation awareness). Its capabilities are not well-known at USAID/Cairo, and the team found little evidence that they are well-known within GOE. The team finds ample evidence, however, that this situation can change during the next year, as draft reports presently under review get issued and discussed externally. 
(4) If the objectives of the project are to be achieved, OEP needs to add to its record of contributing to industrial energy conservation awareness a record of making a difference for energy decisions in Egypt: a record of contributing to energy planning and policymaking in the country. OEP has largely achieved the capability development aims of the energy policy planning project, but it has not yet achieved the policy impact aims. This second step is likely to require a tighter focus on policy issues by OEP, and it will benefit from consistent support by AID where appropriate.

(5) OEP needs to enhance the ability of its staff to appreciate energy issues from the policymaker's point of view and to communicate effectively with a policymaker audience. The team believes that OEP has been wise and farsighted in assuring that its staff capabilities are solid before venturing too far into the risks associated with policy analyses of controversial topics, and it recognizes that the Chairman is an effective representative of OEP in policymaking circles; but it feels that key OEP technical staff members would benefit from a greater sensitivity to the realities of the policymaking world. As OEP increases its interactions with users of its work, actual and potential, a larger proportion of the interactions will be by technical staff members. At this point, key staff members are competent and impressive in communicating with technical colleagues, but the team suggests that -- in most cases -- they are not quite ready yet to deal personally with policymakers and other nontechnical "clients." This gap calls for targeted training and, as appropriate, specific attention in OEP's internal staff discussions to energy policymaking processes in Egypt and the needs, concerns, and communication styles of policymakers.

c. During the final year of the project, the focus of OEP's activities should be refined, considering national needs and OEP's place in the national energy policymaking system. OEP's future depends on its ability to establish its usefulness as well as its quality. With the remaining time and funds in the current project, the aim of both OEP and USAID should be to make progress in this regard, which will call for a re-evaluation of priorities. For example, policy studies should be oriented toward identified policymaker 
needs; and selective audits should be related clearly to priority gaps in data bases, reflecting data needs for high-priority policy studies (and recognizing other industrial energy conservation activities that have emerged recently).

In the team's judgment, the process for this re-evaluation and refinement of priorities should begin with a clear sense of energy policy and information priorities as GOE policymakers see them, developed through dialogues with the policymakers themselves. Tivise policy priorities should be translated into an agenda for policy analysis and studies, which should then be translated into a list of priorities for filling gaps in data bases available to OEP. Out of this kind of perspective should come a relatively clear focus for the final year of the project.

d. In order to sustain the institution-building accomplished by this project, technical assistance should be continued after the end of the project on a more focused basis and at a more modest scale. The institution-building accomplishments of the project to date are striking but, even with more than a year to prepare for it, an abrupt withdrawal of external technical assistance from USAID is likely to mean that much of the progress made so fa: - and the U.S. funds invested in it -. will be wasted. Regardless whether the early stages of the project might have been handled differently, the facts remain that (1) OEP as an energy policy studies organization is still very young; (2) OEP has not yet established itself as a useful contributor to policy dialogue; and (3) OEP has not yet developed a solid base of support within GOE. While progress in these respects can and should be made in the next year, the team is convinced that further short-term external technical assistance will continue to be needed for several more years. This assistance can be at lower overall level of effort than in the current project, and it might be provided through any of a variety of mechanisms. Further USAID support, however, should be related to evidence of GOE interest in policy-related products of OEP.

e. The energy conservation prograrns of OEP have had a positive impact on energy utilization in industries, but OEP's future roles in this sector require clarification. OEP has been instrumental in conducting sixteen energy audits, and nine more are scheduled for 1989, eight with USAID funding support. Beyond that, OEP has under consideration a fourth round of energy audits to be conducted in 1990, before the end of the project's life in June 1990. This fourth round, which will consider office and other buildings as well 
as industrial plants, will need to be developed in close coordination with AID to assure rapid implementation and to avoid redundancies with other industrial conservation programs underway. In order to expedite these activities, considering the time requirement for the contracting modes utilized in the past and the nearness of the end of the project, the team suggests that other mechanisms be considered, such as a "buy-in" to the programs of AID's Office of Energy, Science and Technology Bureau.

OEP, while not an implementing agency, should take action to assure that implementation of the energy audits is accomplished as a result; otherwise a major benefit of these audits will not be achieved, namely the actual savings in energy. This can be done by OEP urging the GOE to allocate funds for the implementation of energy conservation opportunities (ECO's) through whatever channels are appropriate.

OEP will also need to work as closely as possible with the new USAID Energy Conservation Project to provide it whatever technical assistance it can offer and to extract from it any new policy data and policy initiatives that emerge from the new project.

f. Both the Argonne and Meta Systems contracts have been fruitful. Conversations with various AID officials indicated that some individuals have been less than satisfied with the performance of the two contractors during the conduct of the project. The most frequent criticisms related to inadequate interaction with the USAID/Cairo office. Although only Meta Systems worked under a host-country contract, both supporting institutions perceived that their effectiveness in institution-building required the trust of OEP and its leadership, which in turn required a high level of responsiveness. In such situations, USAID needs to be understanding of a contractor's efforts to carefully balance the perceived competing expectations to advise USAID of progress and problems and yet maintain the client's confidence.

In any event, the surcess of this project in achieving its aims is, to a considerable extent, the final measure of a contractor's successful performance, and both ANL and Meta Systems deserve a part of the credit for the substantial accomplishments to date in capability development at OEP. 


\section{RECOMMENDATIONS}

Based on its information-gathering and analysis, the evaluation team recommends that the following steps be taken before the end of the current project in June 1990.

a. USAID/Cairo should:

(1) Assure that appropriate USAID staff are fully familiar with OEP purposes and capabilities. The team recommends that meetings be arranged for OEP's Chairman and senior staff with USAID senior staff (Chief Economist, relevant Office Directors and Associate Directors, and perhaps Deputy Director or Director) 'to discuss OEP's progress and future roles and encourage appropriate USAID staff to learn about OEP and establish links with relevant OEP programs and staff. We believe that USAID will often find OEP information and capabilities to be useful.

(2) Support and participate in dialogues with GOE to expand OEP's channels for communicating perspeftives. Realizing the policy impact objectives of the energy policy planning project depends on finding audiences for the energy planning and analysis capabilities of OEP. Although the main responsibility for this lies with OEP and GOE, USAID can assist the project substantially by supporting the full use by GOE policymakers of the active subgroups of SCE, which can benefit from OEP's assistance. USAID may also be able to reinforce a potentially stronger relationship between OEP and the GOE Ministries of Planning and of Electricity and Energy.

(3) Work closely with OEP regarding priorities for the final year of the project. The specific priorities should arise from intensive interaction between USAID and OEP, in a spirit of collaboration and mutual respect, not from the evaluation team. We suggest, however, that the priorities will include:

- Analyses and policy recommendations related to energy price reform, probably concentrating on options and impacts,

- Analyses and policy recommendations related to the utilization of oil and gas resources in Egypt: for example, longer-term implications of declining reserves, and 
- Analyses and policy recommendations to support the identification and implementation of energy conservation potentials in a variety of sectors.

Regarding the proposed fourth round of selective energy audits, the team suggests that the targets of the individual audits might be broadened beyond the industrial sector alone, to start addressing data needs for energy consumption elsewhere in the national economy (e.g., in large buildings and/or transportation). The team suggests that selection criteria should be re-examined to protect against redundancies with the new USAID/GOE industrial energy conservation program (e.g., probably avoiding metallurgical or chemical plants). And the team observes that, with all services under the current project needing to be completed by June 1990 , the time remaining to plan and carry out the audits is very limited indeed.

(4) Assure effective coordination with OEP in connection with new USAID/Cairo energy project initiatives. As mentioned above, for a variety of reasons, recent USAID/Cairo initiatives in energy conservation and electricity pricing have led to misunderstandings with OEP about relationships with its own programs, which are also supported by USAID. The team recommends that USAID take steps to assure that coordination with OEP is accomplished for these new projects and that an effective general approach to coordination in such cases in the future is developed.

(5) Identify and explore alternatives for a new energy planning assistance mechanism. At a much lower level of effort than the current projec\$, a new activity would emphasize general technical assistance with high-priority policy studies, such as energy pricing analyses, policy analyses related to oil and gas resources, and policy analyses related to the role of conservation in Egyptian energy policy. The team suggests that a total level of effort in the range of $\$ 500,000$ spread over 3 years, with more of the support in the earlier stages, would probably be sufficient.

b. OEP should:

(1) Prepare for possible changes in its financial support base with the end of the current Energy Policy Planning Project. The first priority for OEP is to 
establish beyond any question its usefulness to GOE policymakers and other users of its work, so that its base of financial and institutional support is assured. From the time of the evaluation to the end of the project in June 1990 is little more than 14 months (from April 1989); all services covered by energy policy planning project funding will have to be completed by then. The Meta Systems contract, OEP's only mechanism for technical assistance under the project, ends in little more than eight months. The evaluation team suggests that OEP should develop as rapidly as possible a "crash" program for using the remaining time and money to prepare for the future. Such a program is likely to include an aggressive outreach effort within GOE, a focus on policy studies to meet expressed needs of external parties (perhaps leading to shifts in priorities from program plans developed earlier in the project), and strong steps to get maximum value for the country from the selective industrial energy audits. OEP should be prepared to seek USAID's permission to modify past agreements and contracts if necessary. For example, an extension of the Meta Systems contract to the end of project may be the only way to assure continued technical assistance in the January-June 1990 period.

(2) Emphasize openness and outreach in establishing the important roles that its capabilities are ready to support. Now that so much progress has been made in building OEP's capabilities for energy policy studies and its record in encouraging energy conservation awareness, OEP is well-positioned for a major push to make itself better known to policymakers. The team suggests that OEP: aggressively reach out to parties in GOE and USAID who might be users of OEP information and expertise; open up its information bases and staff capabilities and relatively unconstrained informal interactions with external parties; and actively pursue its plans to issue information summaries, policy reports, and a periodical bulletin about OEP activities.

(3) Continue its shift of emphasis toward policy studies and recommendations, focused on high-priority issues for energy policymaking in Egypt. Based on dialogues with GOE energy policymakers, OEP should endeavor to focus its 
efforts on issues with a high payoff, both in terms of contributing to effective energy utilization in Egypt and in terms of demonstrating its usefulness to the policymaking process. The team suggests that such issues may include impacts of energy price increases, policies regarding the use of oil and gas resources, and policies to encourage the implementation of energy conservation potentials in Egypt; and the team welcomes and supports OEP's growing interest in participating in the policymaking process. More specifically, the team recommends that OEP:

(a) Aggressively relate its policy analysis capabilities to its strong position relative to the role of conservation in Egyptian energy policy. OEP is in an ideal position to become a national leader in understanding and articulating the role of energy conservation in Egyptian energy strategies: i.e. the appropriate balance in attention to the demand side relative to the supply side. The team recommends that the Organization explore ways to apply its analytical tools to this question, drawing upon the knowledge and experience gained from its heavy involvement in conservation work.

(b) Seek opportunities to increase its attention to petroleum and natural gas policy issues. Petroleum and natural gas have grown substantially in their relative importance in Egypt's energy picture; OEP reports administratively to the Minister of Petroleum; and OEP's Chairman is a recognized authority on petroleum sector operations. To the evaluation team, this indicates that OEP should be able to develop a valuable role in policy analyses to liquid and gas fuel supply and use, in close consultation with Egypt's key institutions in this area.

(c) Continue its attention to energy pricing issues, related closely to dialogues with policymakers about priorities for analysis. The next step in the energy pricing work of OEP, which the evaluation team supports and encourages, should be to interact with policymakers about their needs for information and analysis on this issue. Most likely, the team believes, the needs will be related mainly to questions 
about how to reform prices and about the impact of both proposed and actual price increases on the socioeconomic situation in the country.

(4) Build OEP staff skills in communicating with energy policymakers as well as fellow technical experts. The team recommends that OEP seek opportunities for its senior staff and appropriate individuals with policymaking roles to get better acquainted. To contribute to this effort, OEP should consider arranging workshops or other kinds of training mechanisms for its senior staff to prepare them for such a process: e.g., practice in translating technical information into a policymaker's language. The experience of the International Institute of Applied Systems Analysis (IIASA), the U.S. Department of Energy, and other organizations with encouraging interactions between modelers and policymakers should be explored, and effective working relationships with such institutions are encouraged.

(5) Expose OEP staff to a broad range of international experience with policy analysis and modeling. OEP's leading analysts and modelers, having made so much progress in learning to use the tools at hand, can now start putting their tools into international perspective: i.e., investigating uses of those tools in other countries and considering other tools being used for energy planning and policy analysis in developing countries. Professional interactions with peers in other countries should be encouraged, both for what Egypt can learn and for what Egypt can teach. One possibility would be for OEP to host an international conference on policy applications of energy analysis, embracing a wide range of experience and perspectives. 


\section{APPENDIX A. SCOPE OF WORK}

ATTACHMENT NO. 1

\section{ARTICLE I}

Title

Mid Term Evaluation of the Egyptian Energy Policy Planning Subproject No. 263-0123.1

\section{ARTICLE II}

Purpose of the Evaluation

The Mid Term Evaluation is intended to:

1. determine the extent to which the project goals and objectives described in the Project Paper (PP), Project Agreement (PROAG) and as clarified in Project Implementation Letters (PIL) are being implemented and whether can be met within the Life of Project (LOP); and

2. recommend ways in which the project may best respond to the needs of Egypt and in general agreement with AID policy guidelines.

The scope is thus broader than the mere evaluation of project goals and achievements. The Evaluation Team should take the opportunity to make significant input to the project by helping identify changes if needed to maximize the potential for contributing to Egypt's efficient energy utilization in general and to its overall national development in the near and long term.

\section{ARTICLE III}

\section{Project Purpose and Objectives}

The overall goal of the project is the efficient utilization of Egypt's energy resources. The objectives of this subproject is to strengthen Egypt's anergy planning capability and thereby enable the Egyptian government to analyze the relationship between energy policy, including energy pricing, and its economic and political objectives. 
The strategy for achieving this objective is to support the development of an energy planning institution, the Organization for Energy Planning (OEP). The primary functions of OEP are: (1) to develop and maintain an energy data base, (2) to perform integrated analyses of energy data, (3) to undertake energy/economic planning and policy evaluation, (4) to provide engineering support to energy users, particularly with regard to energy conservation, and (5) to undertake field studies that will provide data and information to energy users and suppliers.

The Organization for Energy Planning is an independent legal entity reporting to the Egyptian Minister of Petroleum and Mineral Wealth and programmatically reports to the Supreme Council of Energy. It is the technical secretariat for the Supreme Council of Energy.

\section{ARTICLE IV}

\section{Project Description}

The project started in the fall of 1983 and is expected to continue until June 1989. Basically, the project has the following components: Institution Building, Professional Development Industrial Energy Audits and Special Studies. The Institution Building component is focused on the development of the infrastructure that is necessary for an energy planning organization (for example, computer, office equipment, reference materials, library, professional society membership) and the methods and procedures for carrying out the roles and missions of the Organization (for example, analytical models, planning methods, procurement procedures). The Professional Development components is designed to provide training for OEP and related staff persons involved in the energy planning activities. Although the focus of this activity is on the training of OEP staff, staff from other ministries and energy users (for example, public sector industrial energy managers, private sector, etc.) are expected to receive training in energy planning, and energy conservation activities as they relate to participants involvement in OEP energy planning or policy projects. The third component of the project, Special Studies, includes special priority planning and policy studies that will provide early results from the project and serve as a learning vehicle for OEP and its staff. In particular, the Special Study areas includes Policy Planning and Energy Analysis, Industrial Energy Conservation, 
Energy Pricing, Transportation and Energy Conservation in the electric sector. The special studies are to focus on priority energy policy topics that are expected to be a major part of the OEP mission. Lastly, Industrial Energy Audits are planned for providing OEP with the type of energy data for representative plants so that OEP can establish (a) priorities for energy retrofits to improve energy utilization in industries, (b) energy conservation opportunities, instrument needs and payback periods, and (c) mechanisms for continued supply of energy data for policy analysis by OEP.

OEP currently has a staff of approximately 30 professionals (primarily engineers, economists, and computer specialists) and is hiring new staff as the need arises. Office facilities are established and microcomputers are being used by OEP staff in their policy studies.

\section{ARTICLE V}

\section{Statement of Work}

A. The Evaluation Team will examine the following issues that cut across individual project element:

- goals, objectives and achievements;

- response to GOE energy planning and policy; and

- modifications, if any, to enable OEP achieve its goals more effectively.

The Evaluation Team will address these overall issues as they apply to the four major project elements, i.e., Institutional Building, Professional Development, and Industrial Energy Audits and Special Studies. The Team will address the following specific questions in each of these areas:

\section{Project Plan}

a. Review the project design. Are directions, training plans, programs and activities well-enough defined and resources sufficient to permit implementation? Is the plan in accordance with overall GOE energy planning goals and needs? If there are discrepancies, how may they be resolved?

b. What is the role of the GOE implementing agent vis-a-vis other public and private Egyptian institutions involved in the sector? What are the external factors affecting the program and its implementation? 
c. Is institutional development taking place? Are training, technical assistance and equipment actually being provided through the project?

d. Has USAID provided consistent guidance and policy direction? Has the USAID project monitoring been effective?

e. Are the assumptions upon which the project is based still relevant? What changes, if any, does the team propose?

f. How is the GOE likely to use the information generated by the project? Is the Supreme Council of Energy the GOE institution for effective decisionmaking legislation and implementation of Energy Policies?

g. Is the Energy Node a useful concept? Is combining the Energy Library, Energy Node and the Energy Data Management System into the Energy Information Center an appropriate move?

\section{OEP Institutional Development}

a. What has been the actual versus planned level of staffing? Is the siaff adequately trained to ensure that needs of various task are met? Is using consultant to supplement staff an appropriate institutional building strategy? Has OEP been successful in attracting qualified consultants? What should be the role of outside consultants with respect to OEP staff in the execution of energy projects and studies?

b. What are the exogenous factors in staffing and training as they affect planned and actual performance (available trained labor pool, etc.)?

c. Is OEP involving as the technical secrctariat the Supreme Council of Energy? Comment on OEP organizational structure to generate policy recommendations for Supreme Council of Energy. Describe the GOE organizational structure for the implementation of policies approved by the Supreme Council of Energy. Establish the role of OEP to monitor policies approved by the Supreme Council of Energy.

d. Has OEP established sound and working linages with energy supplying and consuming sectors for both data gathering and policy formulation?

e. Is OEP's management decisionmaking and implementation system functional? Is communication within OEP effective? 
f. What initiatives have OEP taken to indicate it can continue at end of project? Should USAID continue to support OEP? Why and for how long and what conditions?

3. Technical Assistance

Argonne National Laboratory (ANL) (PASA)

a. How effective was ANL in starting up the project?

b. Has it been productive to use a special contractor for technical assistance to start the project and then identify a long term contractor to continue with the work? Is this an effective procedure for GOE to implement USAID assisted projects?

c. Were the changes in the Statement of Work such as the elimination of Resident Manager of the project helpful or harmful to the project?

\section{Meta Systems}

a. Has the Technical Assistance (TA) contractor proved effective? Are the individual roles clearly understood among subcontractors? And between OEP and Meta Systems?

b. Can the Meta Contract objectives be achieved in the present time frame and level of funding?

\section{Recommendations}

a. Are the goals, objectives, and purposes still valid?

b. What changes, if any, are necessary at this point in implementation to assure realization of project goals, objectives and project purposes?

c. Are USAID covenant and GOE needs being addressed?

Industrial Energy Audits

a. Comment on the quality of the energy audits and then follow on audits actions.

b. Recommend procedures and funding to implement attractive Eco's identified in the Energy Audits and the role of OEP in selecting and monitoring the audits to be implemented.

c. What steps, consistent with OEP objectives can be taken to assist the institution sustaining itself? 
B. Required Task

1. Review project documents: including Project Paper; ANL Final Report; MIT Model Report; etc.

2. Interview appropriate USAID, OEP officials and contractor officials involved in project formulation and implementation.

3. Manage the Evaluation Team composed of contractor supplied members and independent members. Prepare an evaluation report with findings, conclusions and rerommendations responding to questions in the Statement of Work.

\section{ARTICLE VI}

Resource Required

The Evaluation Team will be compos sd of four members. The expertise of the team members and their approximate level of effort are:

\section{Team Leader}

The Evaluation Team Leader (TL) should be a senior person with experience in designing and evaluating energy policy and planning projects. The TL is responsible for managing the Evaluation Team and preparing the final draft Evaluation Report that addresses the issues and concerns listed above in ARTICLE V, Statement of Work.

Level of Effort estimate 5 weeks

\section{Economic/Financial Analyst}

The Economic/Energy Planner Team member should have experience in economics and energy economics, and be knowledgeable about USAID evaluation procedures.

Level of Effort estimate 4 weeks

\section{International Energy Planner}

The International Energy Planner Team member should have experience in international energy planning, developing and monitoring international energy programs and USAID evaluation procedures.

Level of Effort estimate 4 weeks 


\section{Egyptian Energy Professional}

The Egyptian Professional should be familiar with Egypt's developmental programs and energy needs. He/she should be familiar with OEP structure and be a resource person to the Evaluation Team on GOE energy and development needs plans, policies and programs. We should also be familiar with the decisionmaking process in Egypt.

The contractor will supply the team leader and Economist/Financial members of the Evaluation Team. The contractor will also be responsible for supplying secretarial and logistical support.

\section{ARTICLE VII}

\section{Reporting Requirements}

1. The Evaluation Team will brief OEP USAID/S\&T and Evaluation Office Staff midway through the evaluation on progress to date.

2. The team will submit a draft report for review by OEP and USAID no later than three weeks after they commence work, and no later than three days prior to their departure from Egypt. USAID and OEP will provide separate written comments on the draft within one week of its receipt. The final report will take these comments into consideration.

3. At the end of their stay in Egypt, the team will present their major findings, conclusions and recommendations to OEP and USAID/Cairo, in separate "debriefings".

4. The team will submit the final evaluation report to USAID and OEP within two weeks of receiving written comments on the draft report from OEP and USAID/Cairo.

5. The format for the report should be as follows:

- Executive Summary should be double spaced and not to exceed six pages and include a listing of the major findings, conclusions and recommendations that summarize the Evaluation in bulletized or matrix format. 
- Main Report, i.e., information and evidence on which conclusions and recommendations are based. The information obtained through the required tasks, described above, should be quantitatively and qualitatively analyzed, and integrated to respond directly to the key questions in the Statement of Work. The report should not exceed forty double-spaced or twenty single-spaced pages.

- Annexes, as appropriate, should include the Statement of Work, a bibliography of documents consulted, a list of individuals interviewed, and their agency affiliation and other information considered appropriate by the team.

\section{ARTICLE VIII}

\section{Relationship and Responsibilities}

The Team Leader working with the Evaluation Team will be responsible for the final report. Independently supplied team members will be responsible for supplying drafts to the team leader for their designated areas as far as possible, the conclusions and recommendations of the team should be a group effort.

\section{ARTICLE IX}

Schedule

The evaluation is scheduled for a four week period beginning on or about October $1,1988$.

\section{ARTTCLE X}

\section{Work Days Ordered}

The Contractor supplied professional will be authorized six days work wecks up to four weeks. The secretarial services are as required by the Evaluation Team. 
APPENDIX B. LOGICAL FRAMEWORK FOR PROJECT

\begin{tabular}{|c|c|c|c|}
\hline & 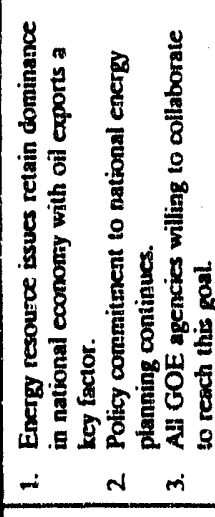 & 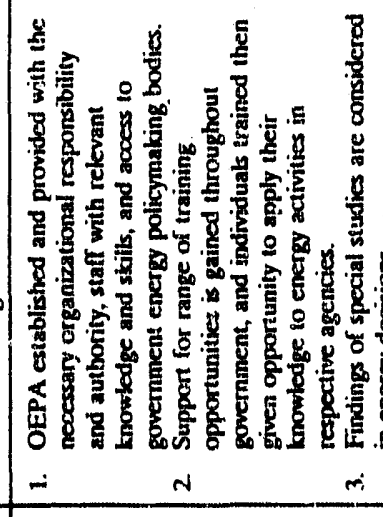 & 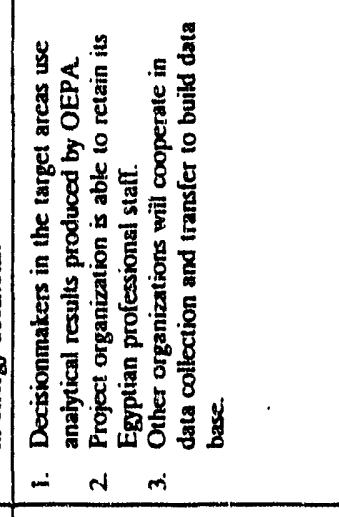 \\
\hline & 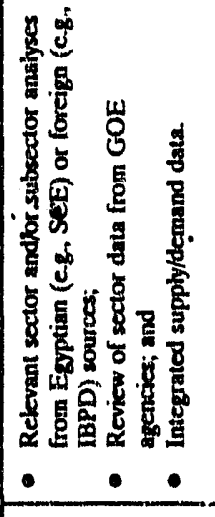 & 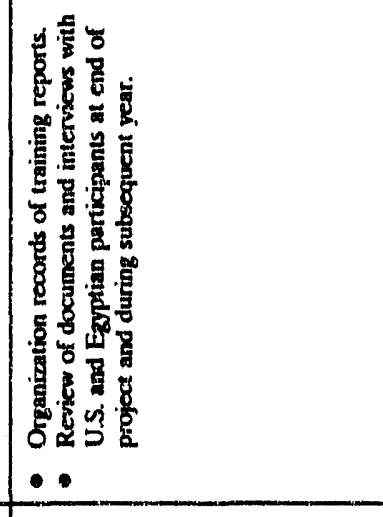 & 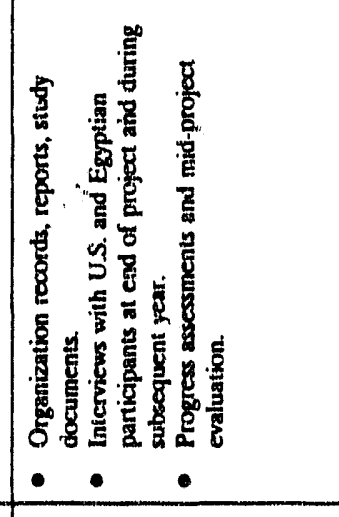 \\
\hline 密 & 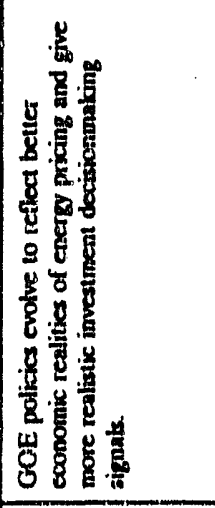 & 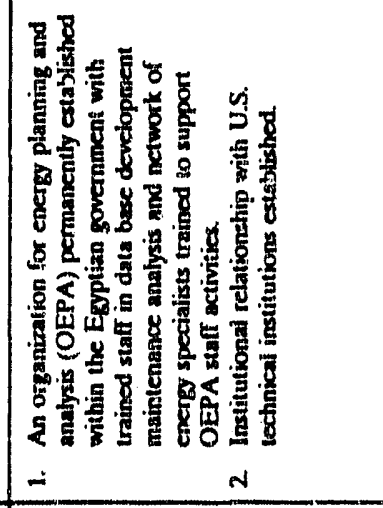 & 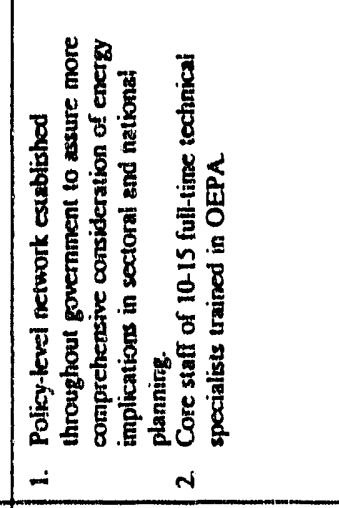 \\
\hline & 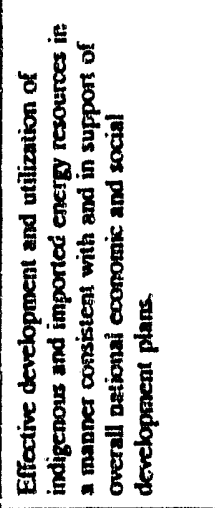 & 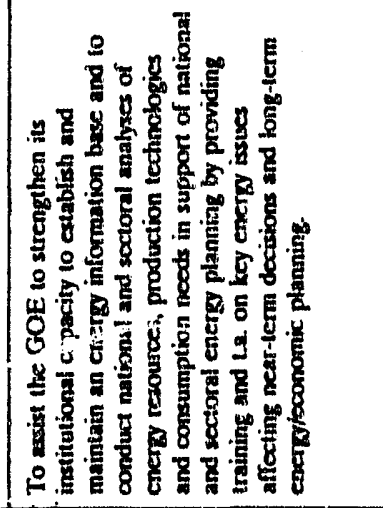 & 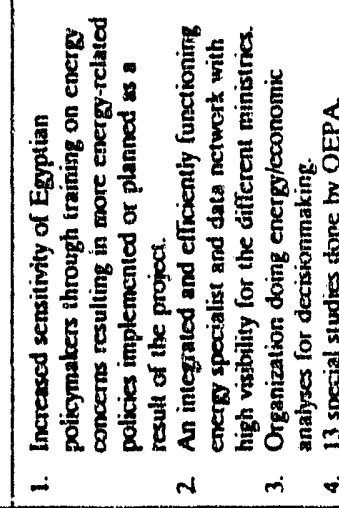 \\
\hline
\end{tabular}

B-1 
B-2

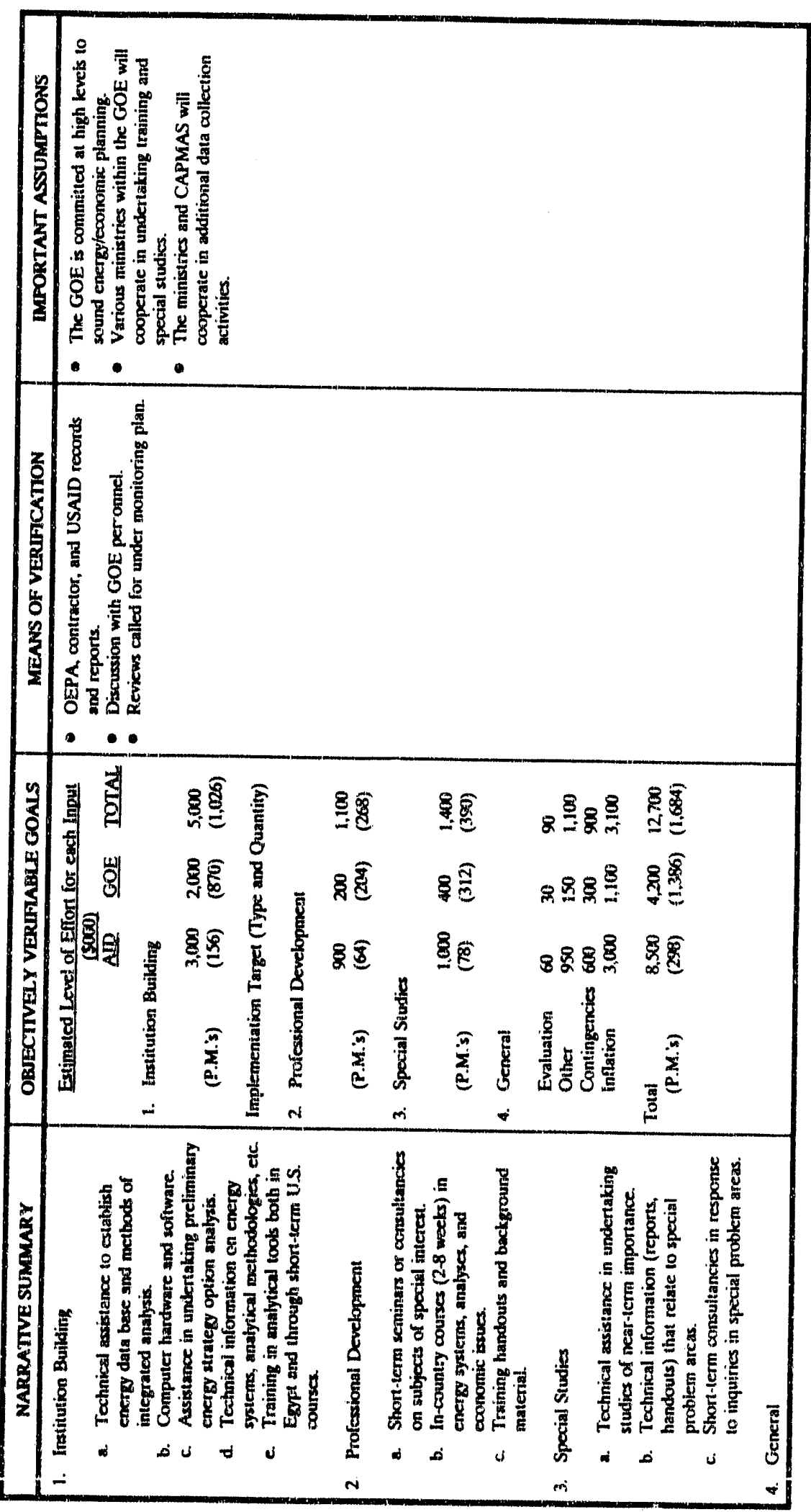




\section{APPENDIX C. LIST OF DOCUMENTS CONSULTED}

Documents consulted as part of the evaluation included

(but were not limited to) the following:

U.S. Agency for International Development, "A.I.D. Evaluation Handbook," A.I.D. Program Design and Evaluation Methodology Report No. 7, Washington, D.C., April 1987.

U.S. Agency for International Development, "Guidelines for Data Collection, Monitoring and Evaluation Plans for A.I.D.-Assisted Projects," A.I.D. Program Design and Methodology Report No. 9, Washington, D.C., April 1987.

U.S. Agency for International Development, "Effective Institution-Building," AID Program Evaluation Discussion Paper No. 11, Washington, D.C., March 1982.

U.S. Agency for International Development, "An Approach to Evaluating the Impact of A.I.D. Projects," AID Program Design and Evaluation Methodology Report No. 5, Washington, D.C., March 1986.

Government of Egypt, Organization for Energy Planning, "Programs anci A rtivities: A Reference Document," Cairo, March 1989.

U.S. Agency for International Development, "Egypt Energy Policy Planning, Renewable Energy Field Testing and Utility Management Grant Project Paper," Washington, D.C., 1982.

U.S. Economic Assistance Program in Egypt, "Second Amendment to Activity Grant Agreement between the Arab Republic of Egypt and the United States of America for the Energy Policy and Renewable Energy Field Testing Project," Cairo, August 28, 1983.

Arab P.epublic of Egypt, "Annual Energy Outlook (1987/88), Draft, March 1989.

Meta Systems, Inc., "World Oil Price Uncertainty: Forecasts, Issues and Some Policy Options for Egypt, September 1988.

Meta Systems, lnc., "Perspectives of Petroleum Pricing in Egypt," undated.

Meta Systems, Inc., "An Energy Demand Simulation Model (OUTSWAM) for Egypt: Interim Report on Consensus Elasticity Estimates, November 1988.

Arab Republic of Egypt, Office of Energy Planning, "Energy Pricing in the Arab Republic of Egypt," undated. 
Arab Republic of Egypt, Office of Energy Planning, "Egypt's Energy Supply During the First and Second Five-Year Plan," by Eng. Hamad Korkor, September 1988.

Arab Republic of Egypt, Office of Energy Planning, "Economic Energy Indicators of Egypt, Draft study, September 1988.

Arab Republic of Egypt, Office of Energy Planning, "Egypt's Energy Demand," by Dr. Ebrahim Gelil, September 1988.

Arab Republic of Egypt, Office of Energy Planning, "Review of Energy Sector Performance in the First Five years," February 1989.

Arab Republic of Egypt, Office of Energy Planning, "The National Cogeneration Project, May 1988.

Foster-Wheeler Co., "Energy Audit of the Helwan Portland Cement Company," May 1988.

Foster-Wheeler Co., "Energy Audit of the El-Nasr Coke \& Chemicals Company," May 1988.

Hagler-Bailly, Inc., "Energy Audit for El-Nasr Coke \& Chemicals Company," September 1988.

Arab Republic of Egypt, Office of Energy Planning, Reference Document on Program Activities, March 1989.

AID/Cairo Energy Conservation and Efficiency Project (263-0140.4).

AlD/Cairo Energy Policy Planning Subproject (263-0123.1) 1982.

Ag-Energikonsult AB, "Energy Conservation in Egypt: Energy Audits in Four Plants," 1988.

U.S. Agency for International Development, Charles Richter, "The Energy Problem of Egypt," November 1986.

Meta Systems, Inc., Dr. F. J. Ahimaz, "Role and Participation in OEP's Development," April 1989.

Background Energy Situation Material from A.I.D. Project Paper 263-0140.3 (various dates 1987 \& 1988).

Memorandum, Chairman Hassan to Dr. R. Rhoda on Selective Auditing Proposals, November 1988.

PASA Agreement between Argonne National Laboratory and USAID, August 29, 1983. 
Argonne National Laboratory Final Report to USAID (Project No. 263-0123.1), March 1986.

Contract between Meta Systems Corporation and USAID signed December 21, 1986. 


\section{APPENDIX D. INDIVIDUALS AND AGENCIES CONTACTED}

U.S. Agency for International Development

AID/Cairo

- William Gelabert, Associate Director, Human Resources Development Cooperation

- Richard Rhoda, Director, Office of Science \& Technology

- Paul O'Farrell, Dircctor, Economics Office

- Sherif Arif, Project Officer

- Khaled Sherif, Economist

- Lottie Erikson, Evaluation Officer

- Victor Duarte, Economist

\section{$\underline{\mathrm{AID} / \mathrm{DC}}$}

- Robert Ichord, ANE/TR

- Robert Archer, ANE/TR

- Diane Romisik, ANE Evaluation Officer

- Eric Peterson, Former Project Officer for EPP Project

- David Jhirad, Senior Energy Advisor, Office of Energy, Bureau of Science \& Technology

\section{U.S. Embassy, Cairo}

- Paul Balabanis, Economics Counselor

\section{Project Contractors}

Argonne National Laboratory

- Tom Wolsko

- Richard Cirillo

Meta Systems

- Franklin Ahimaz, Vice President, Meta Systems Corporation 
D-2

RCG/Hagler-Bailly (parent company of Meta Systems)

- Henri-Claude Bailly, President \& CEO, Hagler/Bailly

- Alain Streicher, Senior Vice President, Hagler/Bailly

\section{Meta Systems subcontractors}

- Sandra Robinson, consultant

- Cherdru Fernando, consultant

\section{Organization for Energy Planning}

- Eng. Ibrahim Hassaan, Chairman

- Dr. Mohi Hussein, Deputy Chairman

- Technical and Administrative Staff

\section{Other Parties}

\section{Parties in Egypt}

- Dr. Selim, Technical Director, Tabbin Institute

- Prof. F. M. El Mahallawy, Univ. of Cairo

- Prof. M. G. Khalafallah, Univ. of Cairo

- Dr. Ahmed Issaway, President, Transport Planning Authority

Dames and Moore

- Dana Younger 


\section{APPENDIX E LESSONS LEARNED FOR OTHER PROJECTS}

The evaluation team suggests that the following lessons, applicable to other A.I.D. projects in Egypt and elsewhere, may be learned from the experience of the USAID/Cairo energy policy planning project to date:

a. Institution-building needs a commitment to sustained long-term support. As many other experiences in developing countries have shown, institution-building is a long, complex process, calling for support beyond an "incubation" stage. Most A.I.D. projects with this aim will need to be associated with technical and other kinds of assistance for more than 4-5 years, even if many things go right. AID's commitment to institution building should normally mean a commitment to staying with the process where it has been deemed worthwhile to initiate it. Otherwise, broader bilateral relationships can be damaged by perceptions of caprice.

b. Personal factors are extremely important in determining the success of institution-building. Such matters as leadership qualities and human relationships, which are difficult to capture in project plans, can dominate the implementation of an institution-building project. In many cases, this suggests a need for particular attention to process variables in project planning.

c. Host-country contracts may be hard to reconcile with efforts by Mission to collaborate actively in project management. Although experiences with host-country contracts vary widely, the history of this project suggests that -- under many sets of conditions -- a host-country contractor can find it difficult to be responsive to its client, the counterpart agency, without seeming unresponsive to USAID. A decision to use the host-country contracting mechanism should be cognizant of a loss of Mission control.

d. Intermediate project evaluations are powerful instruments for keeping a project in line with objectives. The evaluation team believes that this particular intermediate evaluation was a catalyst for activities that moved the project closer to its original aims. This is not to suggest that OEP or USAID played games to get a favorable evaluation. The realization of an upcoming evaluation was simply a reminder to compare present activities with evaluation criteria. In this case, the result was a significant advance in 
capability development and new momentum for policy-oriented programs, to the satisfaction of all concerned.

e. For relatively long-term projects, project plans should be written so as to allow considerable flexibility in responding to changing conditions. Detailed project plans can create problems for a project being implemented in the midst of uncertainty, because some of the partners in the agreement are likely to take them very seriously indeed. One effect can be a loss of resilience in project operation. Another effect can be strains between partners who see PP directives as a contractual agreement and partners who see them as general guidelines permitting considerable flexibility. For multi-year projects, it will often be helpful to differentiate clearly between directives that require PP provisions or PROAG amendments before even minor changes can be made and directives that allow more latitude for modification by less formal and time-consuming mechanisms for joint agreement (e.g., memoranda of understanding). 


\section{APPENDIX F. CRITIQUE OF LOG FRAME}

The Logical Framework (Log Frame) of the USAID/Cairo Energy Policy Planning Project is an ambitious description of laudable objectives. It describes initiatives at three levels of impact on energy planning and analysis in Egypt:

(1) Upgraded institutional capabilities for energy planning and analysis, focused on establishing an organization with the Government of Egypt.

(2) Increased sensitivity on the part of Egyptian policymakers to energy policy facts and options as the result of information and analysis from the new organization.

(3) Improved development and use of indigenous and imported energy resources as a result of enhanced policymaking.

What is unclear is how these three initiatives are meant to relate to one other. The logic of the project implies that they ernerge more or less in series -- 1 , then as a result 2 , then as a result 3 (with some overlaps) -- which means that \#1 must mature rather quickly in order for progress with \#2 and \#3 to be verified by the end of the project. Clearly, however, at least in the Egyptian context, the energy policymaking environment at the top (\#2 and \#3) affects opportunities and mechanisms for the energy planning organization (\#1) fully as much as the converse. When the Log Frame sets an objective of GOE policy evolution "to reflect better economic realities of energy pricing and give more realistic investment decisionmaking signals," for instance, it is addressing processes that extend far beyond the scope of this project alone.

To the degree that the Log Frame is intended as a guide for project evaluation, it would be useful therefore to distinguish between realistic objectives for the project's time span and either (a) objectives for longer-term impact, to be evaluated to some years after the project is completed, or (b) broadly-stated intentions or contextual statements that are not really meant to be interpreted as dimensions for evaluation. It would also be useful to clarify which statements in the first three columns about the user environment are, in essence, assumptions about the social, economic and political context for a successful project vs. intended impacts of the project itself. 
Otherwise, the Log Frame is clearly stated and relatively easy to use. It might be noted that evaluating whether or not a "policy-level network (is) established throughout government" is complicated by unavoidable ambiguities. What constitutes a network is a matter of interpretation; more tangible is an objective stated in terms of what should happen in measurable terms. Similarly, whether or not "institutional relationships with U.S. technical institutions (have been) established" is open to interpretation. An objective focused on types and frequency of contact is more susceptible to evaluation. These things said, however, it is often better to define objectives in terms of the most important targets -- even if some ambiguity is inescapable -- than to limit them to items that can be readily measured. What counts most is not always what is most countable. 
APPENDIX G. INDUSTRIAL ENERGY AUDIT PROGRAM

1. Selection Criteria for Industrial Energy Audits (Sample Evaluation Sheet

2. Application Form for Companies Requesting Energy Audits

3. List of Companies Audited and Results

4. List of New Proposed Energy Audits

5. Measurement Capabilities of Energy Vans and List of Instruments

6. Egypt's Energy Balance, 1986/1987

7. Number of Participants in OEP Training Program 
Evaluation (Sheet)

Company:

File Number:

Expert name:

Signature:

\section{Date:}

\begin{tabular}{|c|l|c|c|c||}
\hline Series & \multicolumn{1}{|c|}{ Selection basis } & Value & Weight \% & Evaluation \% \\
\hline 1 & $\begin{array}{l}\text { Type, Process Units, } \\
\text { Equipment }\end{array}$ & & 10 & \\
\hline 2 & Condition and Age & & 10 & \\
\hline 3 & $\begin{array}{l}\text { Existing Installed } \\
\text { Instrumentation }\end{array}$ & & 5 & \\
\hline 4 & Energy Consumption & & 20 & \\
\hline 5 & $\begin{array}{l}\text { Availability of Technical } \\
\text { Information }\end{array}$ & & 10 & \\
\hline 6 & $\begin{array}{l}\text { Potential Energy } \\
\text { Conservation }\end{array}$ & 30 & \\
\hline 7 & $\begin{array}{l}\text { Export of Domestic } \\
\text { Products }\end{array}$ & & 5 & \\
\hline 8 & Management & & 5 & \\
\hline 9 & Location & & 5 & \\
\hline
\end{tabular}

\section{Brief Description of Selection Basis}

1 - Type, Process Units, Equipment: (10 Degrees)

The factory receives highest score if the process and equipment are common in Egypt, e.g., textile industry, fertilizer, cement et....., and the lowest score if it is unique.

2 - Condition and Age: (10 Degrees)

The older the factory and the worse its technical condition from the point of energy consumption, the higher the score it gets.

3 - Existing Installed Instrumentation: (5 Degrees)

The greater the amount of existing instrumentation, the higher the score, with consideration also given to its operating condition. 
4 - Energy Consumption: (20 Degrees)

The factory receives twenty degrees if its energy consumption is equivalent to 100,000 tons oil annually or more. Ranking decreases by one degree for every 10,000 tons oil lower than 100,000 tons oil consumed annually, i.e., a factory that consumes an equivalent of 80,000 tons oil annually receives 18 degrees.

5 - Availability of Technical Information: (10 Degrees)

The greater the availability of technical data, the higher the score. This is due to the need for origina! design conditions, flow rates, and process arrangement for proper analysis of energy conservation opportunities.

6 - Potential Energy Conservation Improvements: (10 Degrees)

The score for this category is broken up into two parts, half for no or low investment items (housekeeping) and half for items requiring an investment.

7 - Export of Domestic Products: ( $\$$ Degrees)

A plant that exports some or all of its products gets a higher score than one which does not. Roughly, the score should relate to the percentage of product exported. With 5 points equal to $25 \%$ exports.

\section{8 - Management: (5 Degrees)}

An interested and aware management of solving their energy problems, in a cooperative mode, will get higher score.

\section{9- Location: (5 Degrees)}

The factory is given five degrees if it is located within Metro-Politan Cairo, and lower degrees depending on how far it is from the city, and the availability of accommodation facilities in case of distant locations. 
ORGANIZATION POR

ENERGY

PLANNING

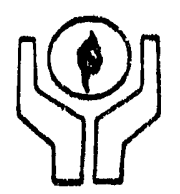

Energy conservation program in EGYPT

\section{Application Form}

Company name:

Location:

Telephone:

Name of energy manager:

Comprany activity:

Products types:

Data and type of any major expansions or modifications:

1- Explain the types of industrial operations used.

2 - Users of energy in the plan (type, year, make):

- Melting furnaces

- Kllns.

- Heavy elec. equipments

- Others (define)

- Boilers

3 - Explain if the process includes heating operations:
A - The purpose of heating
B - The temperature before and after heating
C - The type of fuel used in heating and its properties

4- How do you consider your equipments:

$\begin{array}{ccc}\text { New } & \text { Average age } & \text { Old } \\ \% & \% & \%\end{array}$

5. What are the major energy problems in your plant that you are currently aware of?

6. Explain if any energy conservation steps have been taken in your plant.

7. Do you have process flow chart?

Yes No 
ORGANIZATION POR

ENERGY

PLANNINa

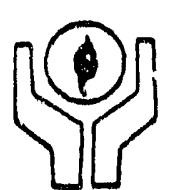

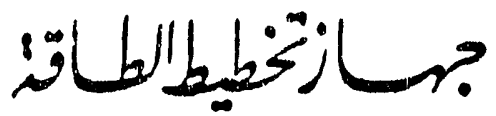

8. Do you have drawings for instrument locations in the plant?

Yes No

9. Do you have drawings for energy flow in the plant?

Yes No

10 - Working hours system:

hr/day shift/day day/week day/year

11 - Do you have equipment list and specifications?

Yes No

12 - State the value of power factor.

13 - What are the biggest individual users of energy?

14 - What is the nature of annual loading?

(constant/variable) 


\begin{tabular}{||l|l|l|l|l|l||}
\hline \hline Month & $\begin{array}{c}\text { Electricity } \\
\text { KWH }\end{array}$ & $\begin{array}{c}\text { Mazout } \\
\text { ton }\end{array}$ & $\begin{array}{c}\text { Solar } \\
\text { ton/liter }\end{array}$ & Others & $\begin{array}{c}\text { Production } \\
\text { unit" }\end{array}$ \\
\hline \hline Jul & & & & & \\
Aug & & & & & \\
Sep & & & & & \\
Oct & & & & & \\
Nov & & & & & \\
Dec & & & & & \\
Jan & & & & & \\
Feb & & & & & \\
Mar & & & & & \\
Apr & & & & & \\
May & & & & & \\
\hline Tun & & & & & \\
\hline
\end{tabular}

16 - Value of annual energy used (L.E.)

17 - Value of annual production (L.E.)

18 - State export \% to total production (if any)

Note: Add information in separate sheet. 
Table G.1

Summary of results of selective energy auditing studies as nine companies (1988)

\begin{tabular}{|c|c|c|c|c|c|c|}
\hline Company name & $\begin{array}{c}\text { Energy } \\
\text { consumption } \\
\text { (TOE) }\end{array}$ & $\begin{array}{l}\text { Annual } \\
\text { energy } \\
\text { saving } \\
\text { (TOE) }\end{array}$ & $\begin{array}{c}\text { Energy } \\
\text { saving } \\
\text { potential } \\
\text { (percent) }\end{array}$ & $\begin{array}{l}\text { Cost of } \\
\text { energy } \\
\text { saved } \\
(1000 \text { s })\end{array}$ & $\begin{array}{c}\text { Investment } \\
\text { cost } \\
(1000 \$)\end{array}$ & $\begin{array}{c}\text { Simple } \\
\text { payback } \\
\text { period } \\
\text { (years) }\end{array}$ \\
\hline \multicolumn{7}{|l|}{ Ministry of Industry } \\
\hline $\begin{array}{l}\text { EL-NASR Co. for Coke \& } \\
\text { Chemicals }\end{array}$ & 75,377 & 35,235 & $47 \%$ & 4,309 & 2,384 & 0.6 \\
\hline MISR Chemical Co. & 67,000 & 7,857 & $12 \%$ & 828 & 241 & 0.3 \\
\hline $\begin{array}{l}\text { EL-NASR Co. for Preserved } \\
\text { Foods }\end{array}$ & 6,103 & 2,066 & $34 \%$ & 432 & 830 & 1.9 \\
\hline EDFINA Food Co. & 4,827 & 1,847 & $38 \%$ & 300 & 140 & 0.46 \\
\hline $\begin{array}{l}\text { The Egyptian Co. for Starch and } \\
\text { Yeast }\end{array}$ & 7,330 & 2,130 & $29 \%$ & 372 & 1,083 & 3 \\
\hline Cairo Co. for Oil \& Soap & 4,600 & 1,004 & $22 \%$ & 125 & 100 & 0.8 \\
\hline SUBTOTAL & 165,237 & 50,139 & $30 \%$ & 6,366 & 4,779 & 0.75 \\
\hline \multicolumn{7}{|l|}{ Ministry of Housing \& Utilities } \\
\hline Helwan Portland Cement Co. & 416,288 & 77,075 & $19 \%$ & 11,946 & 199,440 & 1.6 \\
\hline \multicolumn{7}{|l|}{ Ministry of Health } \\
\hline EL-NASR Pharmaceutical Co. & 9,750 & 1,487 & $15 \%$ & 190 & 95 & 0.5 \\
\hline \multicolumn{7}{|l|}{ Ministry of Petroleum } \\
\hline Alexandria Petroleum Co. & 185,000 & 42,775 & $23 \%$ & 10,868 & $19,82^{\circ}$ & 1.8 \\
\hline TOTAL & 776,275 & 171,476 & $22 \%^{b}$ & 29,370 & 44,143 & 1.5 \\
\hline
\end{tabular}

Includes $30 \mathrm{MW}$ gas turbine at investment $\$ 14,629,000$.

${ }^{b} 10 \%$ of the energy saved is due to housekeeping (i.e. $2.2 \%$ of the total consumed) at a cost of $\$ 373,000$, with a payback period of about 2 months.

Note: $\mathrm{TOE}=$ Tons of Oil Equivalent. 
Table G.2

Summary of results of selective energy auditing studies by AF-Energikonsult (Swedish Co.)

(1985)

\begin{tabular}{|c|c|c|c|c|c|c|}
\hline Company name & $\begin{array}{c}\text { Energy } \\
\text { consumption } \\
\text { (TOE) }\end{array}$ & $\begin{array}{l}\text { Annual } \\
\text { energy } \\
\text { saving } \\
\text { (TOE) }\end{array}$ & $\begin{array}{c}\text { Energy } \\
\text { saving } \\
\text { potential } \\
\text { (percent) }\end{array}$ & $\begin{array}{c}\text { Cost of } \\
\text { energy } \\
\text { saved } \\
(1000 \$)\end{array}$ & $\begin{array}{c}\text { Investment } \\
\text { cost } \\
(1000 \$)\end{array}$ & $\begin{array}{c}\text { Simple } \\
\text { payback } \\
\text { period } \\
\text { (years) }\end{array}$ \\
\hline America Petroleum Refinery Company & 214,136 & 53,745 & $25 \%$ & 6,213 & 17,100 & 2.7 \\
\hline EL-NASR Co. for Sand Bricks & 6,300 & 2,862 & $46 \%$ & 433 & 1,255 & 2.9 \\
\hline EL-NASR Co. for Forging & 6,052 & 3,543 & $58 \%$ & 924 & 990 & 1.1 \\
\hline MISR Helwan Spinning \& Weaving & 30,345 & 9,983 & $33 \%$ & 2,180 & 3,757 & 0.7 \\
\hline Paper Co. for Middle East (SEMO) & & & & 317 & 2,380 & 7.5 \\
\hline \multicolumn{7}{|l|}{ (Co-generation) } \\
\hline TOTAL & 256,833 & 70,133 & $27 \%$ & 10,067 & 25,482 & 2.5 \\
\hline
\end{tabular}

Note: Prices of year 1985: 110 US \$/T.O.E.

In these studies the electrical energy, in its final form has been added to the total consumption.

$\mathrm{TOE}=$ Tons of Oil Equivalent. 
G-9

Table G.3

Summary of results of selective energy auditing studies by Foster Wheeler

(1985)

\begin{tabular}{|c|c|c|c|c|c|c|}
\hline Company name & $\begin{array}{c}\text { Energy } \\
\text { consumption } \\
\text { (TOE) }\end{array}$ & $\begin{array}{c}\text { Annual } \\
\text { energy } \\
\text { saving } \\
\text { (TOE) }\end{array}$ & $\begin{array}{c}\text { Energy } \\
\text { saving } \\
\text { potential } \\
\text { (percent) }\end{array}$ & $\begin{array}{c}\text { Cost of } \\
\text { energy } \\
\text { saved } \\
(1000 \text { ) }\end{array}$ & $\begin{array}{c}\text { Investment } \\
\text { cost } \\
(1000 \$)\end{array}$ & $\begin{array}{c}\text { Simple } \\
\text { payback } \\
\text { period } \\
\text { (years) }\end{array}$ \\
\hline Cairo Dying \& Finishing Co. & 9,369 & & & 1,716 & 1,601 & 0.9 \\
\hline National Co. for Metal Industry & 40,438 & & & 3,981 & 2,515 & 0.63 \\
\hline TOTAL & 49,807 & & & 5,697 & 4,116 & 0.72 \\
\hline
\end{tabular}

Note: Prices 1985: 1 US $\$=1.3 \mathrm{LE}$.

This table is for E.C.O.'s with payback period less than 3 years.

TOE $=$ Tons of Oil Equivalent. 
Selective Auditing

$\underline{1988 / 89}$

\section{I- IOC Contracts}

1 - MISR CO. FOR ALUMINUM (NAGA HAMADY)

2 - EGYPTIAN COPPER INDUSTRIES

3 - GENERAL CO. FOR PAPER INDUSTRY (RAKTA)

4 - EL-NASR CO. FOR FERTILIZER (SUEZ)

5 - EGYPTIAN CO. FOR SUGAR (NAGA HAMADI)

6 - DELDA INDUSTRIAL CO. (IDEAL)

7 - TRANSPORTATION \& ENGINEERING CO. (ALEX)

8 - EGYPTIAN CO. FOR LEATHER INDUSTRY

II - OEP in Cooperation with Egyptian consultants

1 - EL-KATAMMIA LIME MANUFACTURERS

(private sector) 


$$
\underline{2}=\vdots
$$

$\% \pi=\frac{7 x}{7}=-$ -

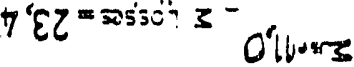

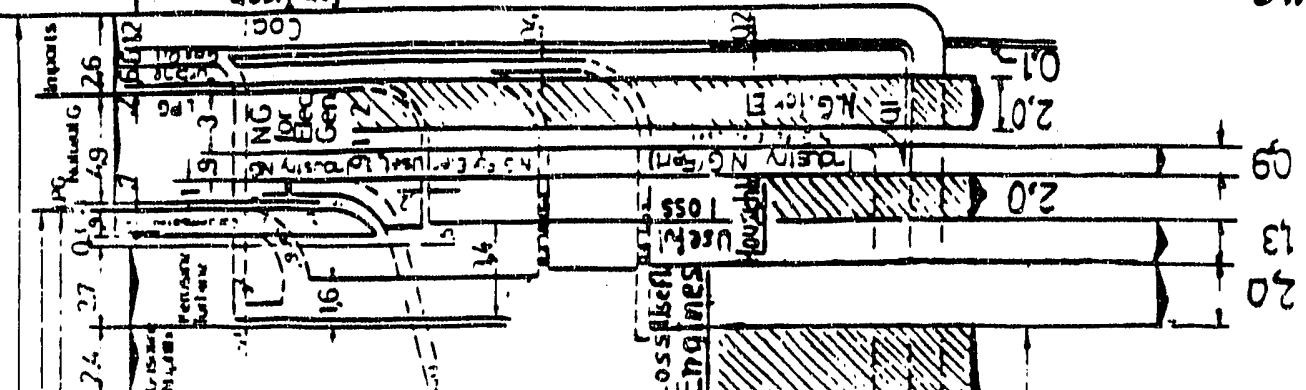

os
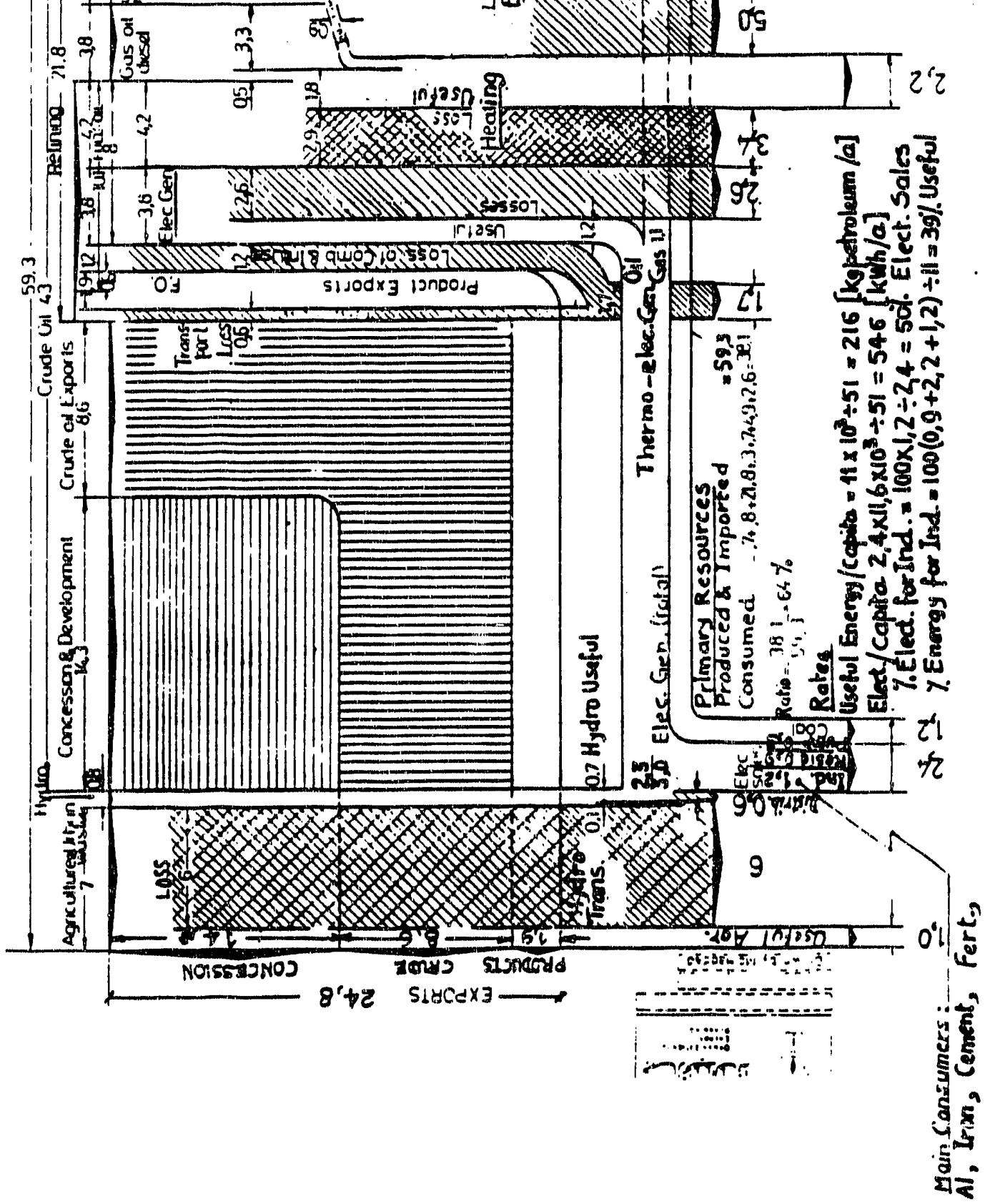
G-12

Table G.4

Participants at training courses for energy managers 1983-1984-1985

\begin{tabular}{||l|r|r|r|c||}
\hline \multicolumn{1}{|c|}{ Participants from } & 1983 & 1984 & 1985 & Total \\
\hline \hline Ministries of: & & & & \\
- Industry & 60 & 89 & 98 & 247 \\
- Petroleum & 4 & 17 & 8 & 29 \\
- Electricity, Energy & 8 & 1 & 6 & 15 \\
- Housing & 8 & 8 & 8 & 24 \\
- Supply & - & - & - & - \\
- Health & - & - & - & - \\
- Transport & - & 10 & 8 & 18 \\
- Military Production & - & 6 & 4 & 10 \\
\hline Others: & & & & \\
- Suez Canal Authority & 1 & 5 & 4 & 10 \\
- Water Authority & 1 & - & - & 1 \\
- Sanitary \& Sewage & 1 & - & - & 1 \\
\hline \hline TOTAL & 83 & 136 & 136 & 355 \\
\hline
\end{tabular}




\section{APPENDIX H. OEP ACTIVITY IMPLEMENTATION (Professor Kamel)}

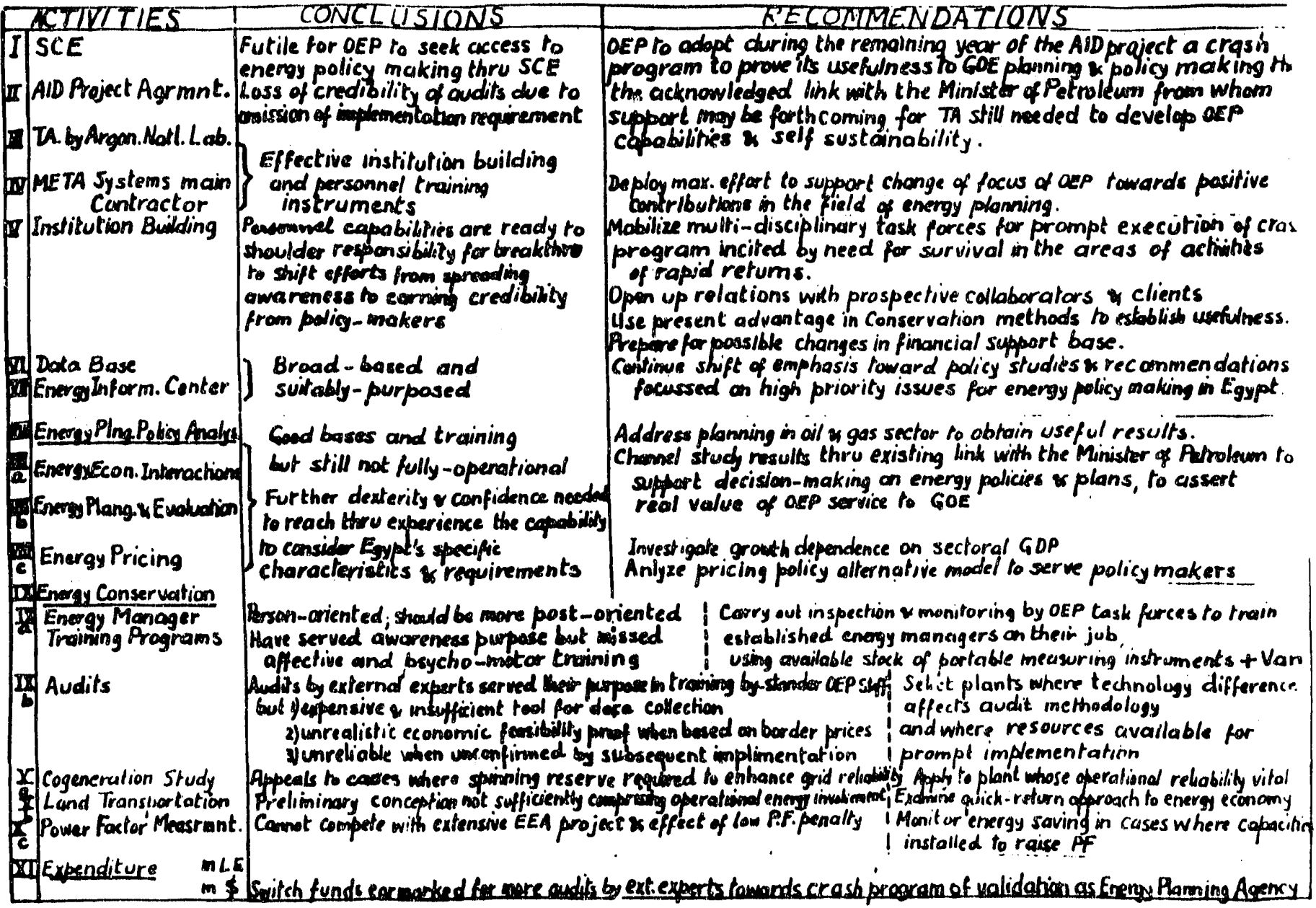




\section{APPENDIX I. LIST OF ACRONYMS}

A.I.D. - U.S. Agency for International Development

ANL - Argonne National Laboratory

CAPMAS - Central Authority for Population, Mobilization, and Statistics, Government of Egypt

DOE - U.S. Department of Energy

ECO - Energy conservation opportunity

EEA - Egyptian Electric Authority

EIC - Energy Information Center, Organization for Energy Planning

ENPEP - Energy and Power Evaluation Program, a microcomputer modeling system for energy analysis

GOE - Government of Egypt

IIASA - International Institute for Applied Systems Analysis

OEP - Organization for Energy Planning, Government of Egypt

OEPA - Organization for Energy Planning and Analysis (proposed 1982 -- became OEP)

ORNL - Oak Ridge National Laboratory

PASA - Participating Agency Service Agreement

PP - Project Paper (A.I.D.)

PROAG - Project Activity Grant Agreement (A.I.D./GOE)

RFP - Request for Proposal

SCE - Supreme Council on Energy, Government of Egypt

USAID - Cairo Mission of A.I.D.

WASP - Wien Automated Supply Program, an analytical tool for power system expansion planning 


\section{INTERNAL DISTRIBUTION}
1. D. E. Bartine
2. F. P. Baxter
3. J. B. Cannon
4. A. E. Ekkebus
5. S. D. Floyd
6. W. Fulkerson
7. U. Gat
8. D. L. Greene
9. L. J. Hill
10. E. L. Hillsman
11. D. W. Jones
12. E. H. Krieg
13. M. A. Kuliasha
14. A. S. Loebl
15. W. R. Mixon
16. H. B. Piper
17. J. W. Ranney
18. D. E. Reichle
19. T. Rizy
20. R. H. Selden
21. R. B. Shelton
22. G. G. Stevenson
23. S. H. Stow
24. D. P. Vogt
25-34. T. J. Wilbanks
35. S. B. Wright
36. ORNL Patent Office
37. Central Research Library
38. Document Reference Section
39. Laboratory Records
40. Laboratory Records - RC

\section{EXTERNAL DISTRIBUTION}

41. F. T. Al-Saadvon, 1124 W. Yoakum Avenue, Kingsville, TX 78363

42. T. Alereza, ADM Associates, Inc., 3299 Ramos Circle, Sacramento, CA 95827

43. H. Amistad, Rural Route 2, Box 2191C, Brunswick, ME 04011

44. R. Arellanes, Idaho Department of Water Resources, Division of Energy, Statehouse Mail, Boise, ID 83720

45. J. H. Ashworth. Meridian Corporation, 4300 King Street, Suite 400, Alexandria, VA 22302

46. P. D. Blair, Manager, Energy and Materials, U.S. Congress, Office of Technology Assessment, Washington, DC 20510

47. R. D. Brown, W-739, The Mitre Corporation, 7525 Colshire Drive, McLean, VA 22102

48. B. G. Buchanan, Computer Sciences Department, University of Pittsburgh, 206 Mineral Industries Building, Pittsburgh, PA 15260

49. W. Buehring, Argonne National Laboratory, 9700 South Cass Avenue, EID/362, Argonne, IL 60439

50. D. Bushari, Gulf Power Company, 500 Bayfront Parkway, P.O. Box 1151, Pensacola, FL 32520-1151

51. D. Chapman, The World Bank, 1818 H Street, NW, Room S-5119, Washington, DC 20433

52. M. Cherniack, Director, Asia Regional Office, 10/4 Sol 49/7 Sukhumvit, Bangkok 10110, Thailand 
53. T. Chrisiian, U.S. Department of Energy, NEIC, 1000 Independence Avenue, SW, Room 1F-048, Washington, DC 20585

54. R. R. Cirillo, Argonne National Laboratory, 9700 South Cass Avenur. EID/362, Argonne, IL 60439

55. G. Crawford, Room 1, Bailer Hall, University of Kansas, Lawrence, KS 66045

56. F. L. Culler, 3412 Hillview Avenue, Palo Alto, CA 94303

57. E. D. Daugherty, Tennessee Valley Authority, 3N78A Missionary Ridge Place, Chattanooga, TN 37402

58. J. F. DeLeon-Guerrero, Commonwealth Energy Office, P.O. Box 340, Saipan, MP 96950

59. F. P. Diemer, U.S. Department of Energy, EI-43, 1000 Independence Averiue, SW, Washington, DC 20585

60. L. Dienes, Department of Geography, University of Kansas, Lawrence, KS 66045

61. C. E. Dorgan, University of Wisconsin, 432 North Lake Street, Madison, WI 53706

62. R. S. Eckaus, Department of Economics, Massachusetts Institute of Technology, Cambridge, MA 02146

63. R. Erickson, Energy Applications Consulting, 835 Deer Lane, Guffey, CO 80820

64. A. Faverqui, Barakat \& Chamberlain, 180 Grand Avenue, Suite 1090, Oakland, CA 94612

65. Federal Energy Regulatory Commission, Library, Room 8502, 825 North Capitol Street, NE, Washington, DC 20426

66. G. Fenwick, USDA, Office of Energy, 14th \& Independence Avenue, SW, Room 144-E, Administration Building, Washington, DC 20250-2600

67. M. J. Ford, New Mexico Energy, Minerals and Natural Resources Department, Energy Conservation Division, 2040 South Pacheco Street, Santa FE, NM 87505

68. R. Foster, SWTDI/NMSU, P.O. Box 30001, Department 3 SOL, Las Cruces, NM 88003-0001

69. L. Frantzis, Arthur D. Little, Inc, 20 Acorn Park, Cambridge, MA 02140

70. K. M. Friedman, 11321 Dunleith Place, Gaithersburg, MD 20878

71. L. P. Golan, 386-2 College Avenue, Clemson, SC 29634-0929

72. B. Goldberg, NAHB National Research Center, 400 Prince George Boulevard, Upper Marlboro, MD 20772

73. W. A. Goodwin, Campus Box 5012, Tennessee Tech University, Cookeville, TN 38505

74. W. A. Gross, Department of Mechanical Engineering, The University of New Mexico, Albuquerque, NM 87131

75. C. R. Guinn, Deputy Commissioner for Policy and Planning, New York State Energy Office, Two Rockefeller Plaza, Albany, NY 12223

76. N. P. Hall, Management Analyst, Department of Energy and Natural Resources, 325 West Adams, Room 300, Springfield, IL 62704

77. S. J. Hansen, 177 Defense Highway, Suite 5, Annapolis, MD 21401

78. E. W. Hauser, CART, CEAS, ASU, Tempe AZ 85087-6206

79. N. M. Hawkins, 371 Loew Hall, FH-10, University of Washington, Seattle, WA 98195 
80. A. Hirsch, Vice President, Environmental Sciences and Director, Washington Operations, Midwest Research Institute, 5109 Leesburg Pike, Suite 414, Falls Church, VA 22041

81. J. Holmes, 1948 Martha's Road, Alexandria, VA 22307-1952

82. J. Holmstrom, Bonneville Power, P.O. Box 3621, Portland, OR 97208

83. H. M. Ingram, Director, Udall Center for Studies in Public Policy, The University of Arizona, 803/811 East First Street, Tucson, AZ 85719

84. G. A. Jackins, P.O. Box 360687, Birmingham, AL 35236

85. J. Jennings, ERCE, 621 Southwest Alder, Suite 520, Portland, OR 97205

86. G. J. Jones, Division 6223, Sandia National Laboratories, P.O. Box 5800, Albuquerque, NM 87185

87. R. E. Kasperson, 201 Joy Koad, Woodstock, CT 06281

88. B. S. Kavanaugh, Center for Energy Studies, Louisiana State University, Baton Rouge, LA 70803-0301

89. P. J. King, Program Officer, U.S. Department of Energy/BSO, O'Neill Federal Building, Room 1197, Boston, MA 02222

90. C. E. Klotz, Argonne National Laboratory, SPO Building 315, 9700 South Cass Avenue, Azgonne, IL 60439

91. C. G. Knight, Penn State University, 302 Walker Building, University Park, PA 16802

92. W. E. Krauss, Gas Research Institute, 8600 West Bryn Mawr Avenue, Chicago, IL 60631

93. C. J. Langenfield, U.S. Department of Energy', 1000 Independence Avenue, SW, PE-62, Room 7H-034, Washington, D.C. 2058:

94. T. J. Lineham, Washington State Energy Office, 809 Legion SE, FA-12, Olympia, WA 98503

95. A. Lovins, 1739 Snowmass Creek Road, Snowmass, CO 81654

36. C. D. MacCracken, President, Calmac Manufacturing Corporation, 101 West Sheffield Avenue, P.O. Box 710, Englewood, N.J 07631

97. P. P. Malanchuk, University Libraries, University of Florida, 142 Library West, Gainesville, FL 32611

98. B. D. McGuire, Regal Industries, Route 1, Box 45, wrothersville, IN 47239

99. R. O. McMillan, District of Columbia Energy Office, 613 G Street, NW, Washington, DC 20001

100. D. McMurtrey, EG\&G Idaho, Inc., P.O. Box 1625, Idaho Falls, ID 83415

101. M. Mintz, Argonne National Laboratory, F dilding 362-2B, 9700 South Cass Avenue, Argonne, IL 60439

102. C. E. Mulholland, 3211 Jermantown Roud, $P \cap$. Box 1C:30, Fairfax, WA 22030

103. C. Olson, Public Transportation Library State Campus, Building 4, Room 212, 1120 Washington Avenue, Albany, NY 12232

104. T. Olson, California Energy Commission, Export Program, 1516 9th Street, MS45, Sacramento, CA 95814-5512

105. Pennsylvania Transportation Institite, Working Collection, Research Building, University Park, PA 16802

106. R. L. Perrine, Professor of Engineering and Applied Science, University of California, Civil Engineering Department, Engineering I, Room 2066, Los Angeles, CA 90024

107. C. H. Petrich, J1, Kemang Dalam, VI, Blok D-1, Kemang Indah - Kimpleks Pusri, Jakarta Splatan 12730 Indonesia 
108. M. Philips, International Institute for Energy Conss vation, $420 \mathrm{C}$ Street, NE, Washington, DC 20002

109. K. R. Polenske, Massachusetts Institute of Technology, Room 9-535, 77 Massachusetts Avenue, Cambridge, MA 02139

110. L. Prikryl, BCI, 180 Grand Avenue, Suite 1090, Oakland, CA 94612

111. L. Purcell, Electricity Supply Board, Lower Fitzwilliam Street, Dublin 2 Ireland

112. D. Reay, Supervisor, Arizona Public Service Company, P.O. Box 53999, Station 1365, Phoenix, AZ 85072-3999

113. I. B. Rickling, Flordia Solar Energy Center, 300 State Road 401, Cape Canaveral, FL 32920

114. F. Roach, A-41, MS B299, Los Alamos National Laboratory, Los Alamos, NM 87545

115. M. K. Roelofs, Minnesota Department of Public Service, 900 American Center Building, 150 East Kellogg, St. Paul, MN 55101

116. M. Ross, Physics Department, University of Michigan, Ann Arbor, MI 48109

117. A. J. Sabadell, A.I.D./R\&D/EIN, Office of Energy and Infrastructure, Bureau for Research and Development, Room 508, SA18, Washington, DC 20523-1810

118. R. A. Schmidt, CDR, U.S. Army Missile Ccmmand, Redstone Scientific Information Center, AMSMI-RD-CS-R/Documents, Redstone Arsenal, AL 35898-5241

119. T. Secrest, Pacific Northwest Laboratory, P.O. Box 999, KS-02, Richland, WA 99352

120. C. F. Sepsy, 'The Ohio State University, Mechanical Engineering Department, 206 West 18th Avenue, Columbus, $\mathrm{OH} 43210$

121. K. G. Sheinkopf, Director of Special Projects, Solar Energy Industries Association, Suite 805, 777 North Capitol Street, NE, Washington, DC 20002 4226

122. J. B. Shrago, Director, Office of Technology Transfer, 405 Kirkland Hall, Vanderbilt University, Nashville, TN 37240

123. K. C. Sinha, School of Civil Engineering, Purdue University, West Lafayette, IN 47907

124. L. Skup, Senior Policy Analyst, Energy Programs Division, Illinois Commerce Commission, 100 West Randolph Street, Chicago, IL 60601

125. G. Smith, Oak Ridge Associated Universities, 1019 19th Street, NW, Washington, DC. 20036

126. G. L. Smith, Bechtel Group, Inc., 50 Beale Street (50/15/A70), San Francisco, CA 94105-1895

127. E. Stancell, U.S. Department of Energy, CE-52, 1000 Independence Avenue, SW, Washington, DC 20585

128. J. H. Staniunas, Business Development, International Fuel Cells, 195 Governors Highway, P.O. Box 739. South Windsor, CT 06074

129. W. R. Steinhurst, Vermont Department of Public Service, 120 State Street, Montpelier, VT 05602

130. R. Sternberg, Environmental, Urban, and Geographic Studies, Montclair State College, Upper Montclair, NJ 07043

131. A. Taylor, Coordinator, Department of Mines and Energy Province of Newfoundland and Laborador, Energy Programs Division, P.O. Box 8700. St. Johns, NFLD Canada A1B 436 
132. D. Thompson, Department of City and Regional Planning, University of Pennsylvania, 3400 Walnut Street, Room 10A, Philadelphia, PA 19104-6208

133. C. Tighe, Meridian Corporation, 4500 King Street, Suite 400 , Alexandria, VA 22302

134. J. Torabzadeh, Department of Mechanical Engineering, California State University, 1250 Bellflower Boulevard, Long Beach, CA 90840

135. D. Violette, RCG/Hagler Bailly, Incorporated, P.O. Drawer O, Boulder, CO 80306-1906

136. J. R. Warner. ACEC/RMF, STE 802, 1015 15th Street, NW, Washington, DC 20005

137. M. Williams, Professor, Department of Economics, Northern Illinois University, DeKalb, IL 60115

138. T. E. Williams, 3318 Prince William Drive, Fairfax, VA 22031-3022

139. E. Woychik, 1300 Clay Street, Suite 600, Oakland, CA 94602

140. D. W. Yarbrough, Tennessee Technological University, P.O. Box 5013, Cookeville, TN 38505

141. D. Yergin, Cambridge Energy Research Association, 20 University Road, Cambridge, MA 02138

142. R. Yoder, Pacific Power and Light, 920 Southwest Sixth, 440 PFFC, Portland, OR 37204

143. C. Young-Hinds, VI Energy Office, Old Customs House, Frederiksted, VI 00840

144. Office of Assistant Manager for Energy Research and Development, DOE OR, P.O. Box 2001, Oak Ridge, TN 37831-8600

145-146. OSTI, U.S. Department of Energy, P.O. Box 62, Oak Ridge, TN 37831

147-170. Planning and Coordination External Distribution 

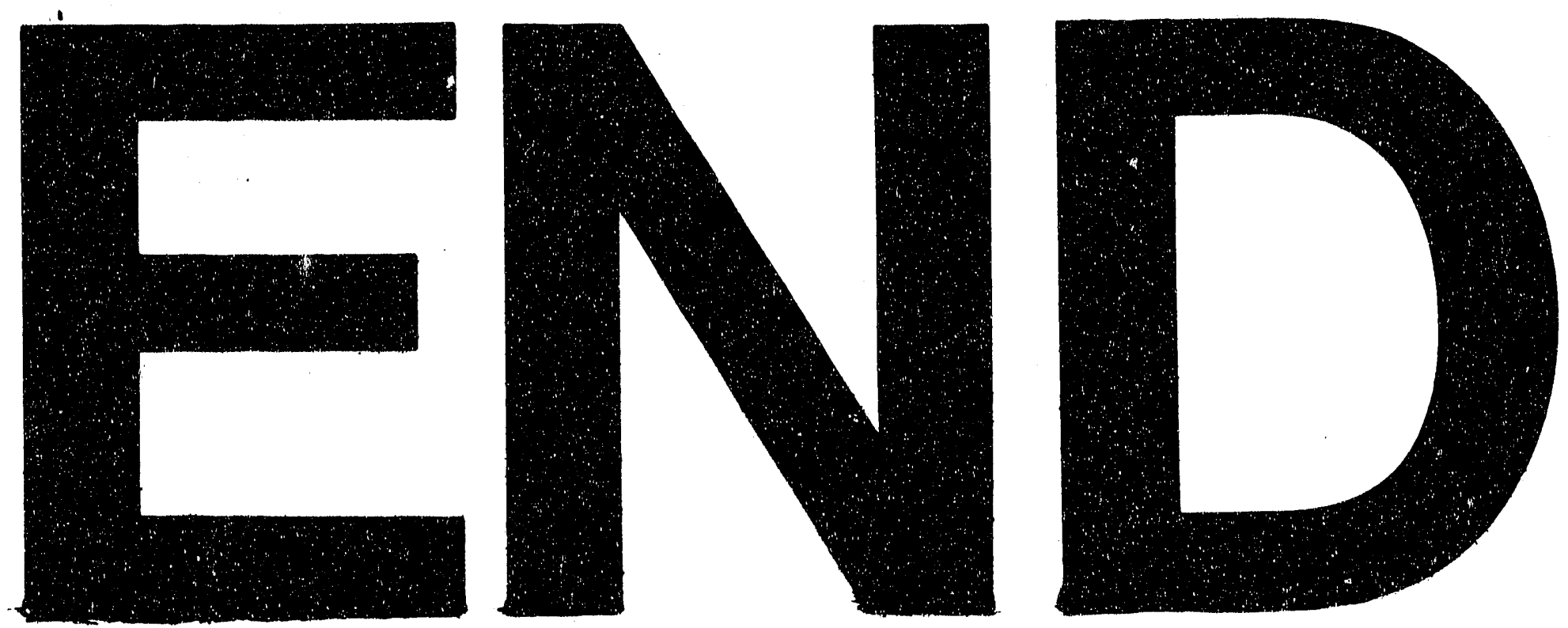

-
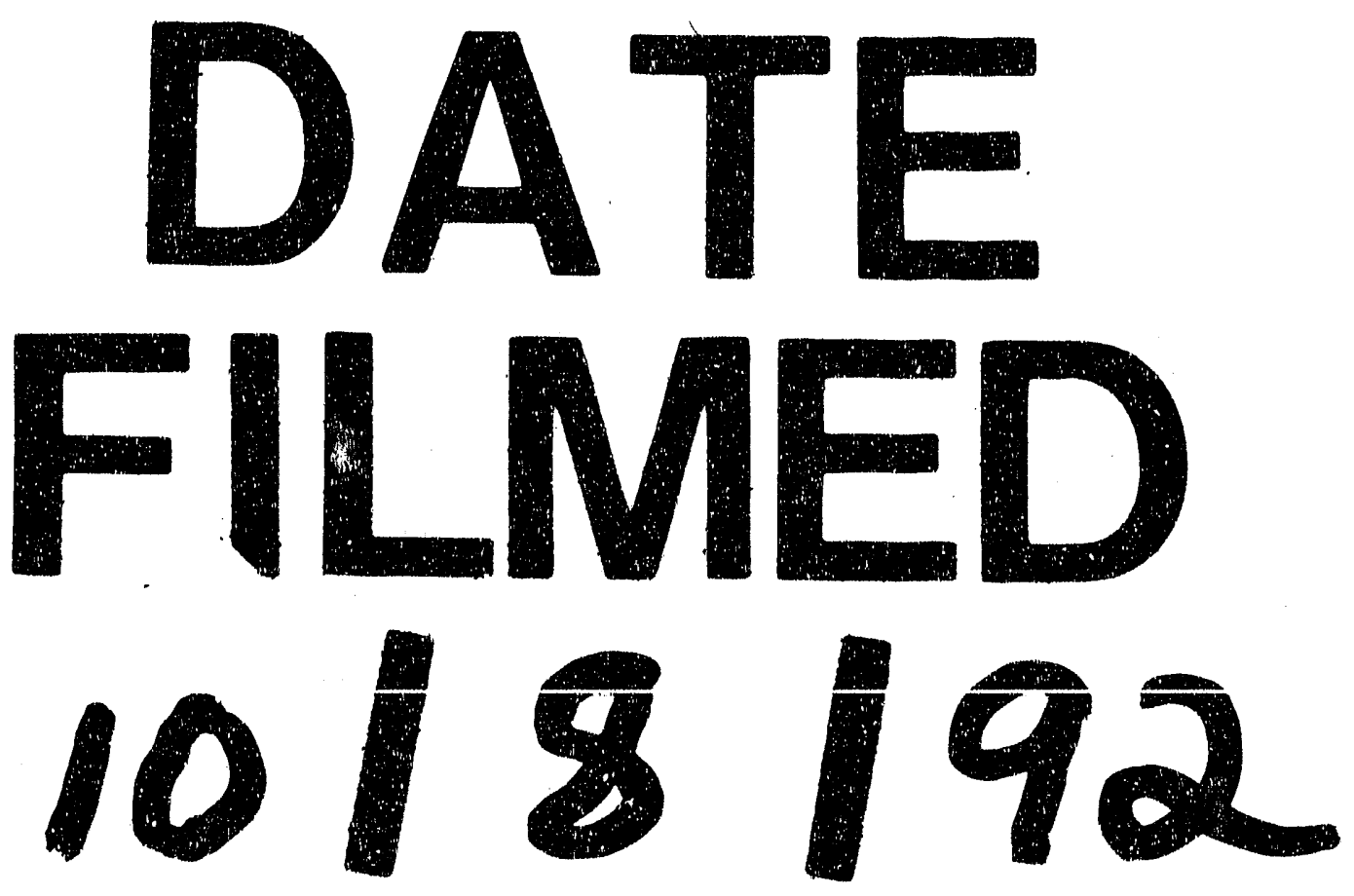

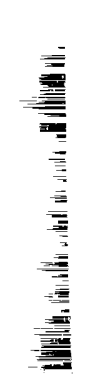


